\title{
Testing molecular barcodes: Invariant mitochondrial DNA sequences vs the larval and adult morphology of West Palaearctic Pandasyopthalmus species (Diptera: Syrphidae: Paragini)
}

\author{
Santos ROJO ${ }^{1}$, Gunilla STÅHLS ${ }^{2}$, Celeste PÉREZ-BAÑóN ${ }^{1}$ and M. Ángeles MARCOS-GARCÍA ${ }^{1}$ \\ ${ }^{1}$ Instituto Universitario CIBIO (Centro Iberoamericano de la Biodiversidad), Universidad de Alicante, Alicante E-03080, Spain; \\ e-mail: santos.rojo@ua.es \\ ${ }^{2}$ Finnish Museum of Natural History, University of Helsinki, P.O. Box 17, FIN-00014 Helsinki, Finland
}

Key words. Diptera, Syrphidae, Paragus, barcoding, immature stages, morphology, ITS2, COI, Palaearctic

\begin{abstract}
The intra- and interspecific variability in the West Palaearctic tibialis-group species of the subgenus Pandasyopthalmus (Diptera: Syrphidae: Paragus) was analysed. Novel immature and molecular characters were studied and the traditionally used adult characters reviewed with the aim of establishing the status of the most widespread taxa of the tibialis-group in the Palaearctic region. Moreover, a review of the morphology of the larvae of the subgenus Pandasyopthalmus is also presented and includes the first description of the chaetotaxy of the larval head of Syrphidae. The larval morphology showed a continuum between two extremes. There is intraspecific variability in the male genitalia characters typically used for diagnostic species identification in this group. Molecular characters of the mitochondrial cytochrome $c$-oxidase subunit I (COI) was invariant for the West Palaearctic Pandasyopthalmus taxa analysed. Despite the fact that no great differences were found when compared with Afrotropical tibialis-group individuals (uncorrected pairwise divergence $0.17-0.35 \%$ ), the divergences of the West Palaearctic vs. Nearctic and Austral-Oriental tibialis-group taxa varied between 1.15-2.75\% (uncorrected pairwise divergence). Molecular characters of the nuclear ribosomal internal transcribed spacer region (ITS2) revealed several molecular haplotypes of a dinucleotide repeat that was not constrained to morphospecies or to populations of the same geographic origin. The closely related and morphologically similar species of the tibialis-group known from the West Palaearctic region are separable in most cases only by the shape and size of male postgonites. The results of this study support the presence of a single polymorphic taxon in the West Palaearctic region (or a very recent origin of the taxa studied). Moreover larval morphology and the lack of a clear relation between ITS2 haplotypes and the geographic distribution or adult morphology, support the taxonomic implications of barcode taxonomy based on mitochondrial DNA for this speciesgroup of Syrphidae.
\end{abstract}

\section{INTRODUCTION}

Paragus Latreille, 1804 the only genus in the tribe Paragini, is found on all continents other than South America and Antarctica. They are small hoverflies, mainly black in colour, with a black abdomen, except tergites 3-5, which are usually red-orange to dark yellow. At the beginning of the 20th century, most authors recognized that only a few widespread species among about twenty taxa worldwide (Kertész, 1910; Bezzi, 1915; Sack, 1929).

Stuckenberg (1954) was the first to use the male genitalia in combination with more traditional characters of adult morphology to divide Paragus into two subgenera: Paragus s. str. and Pandasyopthalmus. Most of the former widespread $P$. tibialis (Fallén, 1817) species complex belong to the subgenus Pandasyopthalmus, which is divided into two species groups, longiventris-and tibialisgroups, on the basis of the shape of the hypandrium, and facial and abdominal morphology (Stuckenberg, op. cit.). As far as we know, no representatives of the longiventrisgroup exist in the Palaearctic region, but the following seven species of the tibialis-group are recognized: Paragus albipes (Gimmerthal, 1842) [= P. abrograns Goeldlin de Tiefenau, 1971 sensu authors; $=P$. rufocinctus (Bruneti, 1908) sensu authors], P. ascoensis
Goeldlin de Tiefenau \& Lucas, 1981, P. coadunatus (Rondani, 1847), P. constrictus Simic, 1986, P. haemorrhous Meigen, 1822, $P$. politus Wiedemann, 1830 and $P$. tibialis (Fallén, 1817) (Vujic et al., 1998). In the Palaearctic catalogue (Peck, 1988), the species $P$. jozanus Matsumura, 1916 is included in Pandasyopthalmus. This species and a few species described from the eastern Palaearctic, Oriental and Afrotropical regions, however, fit neither of the above subgenera, as noted by Thompson \& Ghorpadé (1992) and Kassebeer (1999), and therefore are not considered in the present study.

Paragus haemorrhous and P. tibialis are the most common and widely distributed species of Pandasyopthalmus in the Palaearctic region. The former is the only species of this subgenus recorded for the Nearctic and Neotropical (Central America) regions and also present in the Oriental and Afrotropical regions (Stuckenberg, 1954; Vockeroth, 1986; Claussen \& Weipert, 2004). The geographic distributions of the other Palaearctic species are more restricted (Dirickx, 1994; Vujic et al., 1998), except $P$. politus, which is common in the Oriental and Australian regions (Thompson \& Ghorpadé, 1992) (see Table 1).

The taxonomic descriptions of male genitalia usually include figures of lateral and ventral views of the hypandrium and surstyli, but the shape and size of the postgo- 
Table 1. Pandasyopthalmus species cited in this paper. 1-8 Palaearctic species currently recognized. Distribution: $\mathrm{Au}=$ Australian, Af $=$ Afrotropical, $\mathrm{N}=$ Nearctic, $\mathrm{Nt}=$ Neotropical Or $=$ Oriental, $\mathrm{Pa}=$ Palaearctic. Data available in this study: $\mathrm{Ad}$ $=$ adult morphology, $\mathrm{Lv}=$ larval morphology, $\mathrm{Mo}=$ molecular analysis.

\begin{tabular}{|c|c|c|c|}
\hline Species & Distribution & $\begin{array}{l}\text { Taxonomic- } \\
\text { group }\end{array}$ & This study \\
\hline 1. P. albipes & Or, $\mathrm{Pa}$ & tibialis-group & Not analysed \\
\hline 2. P. ascoensis & $\mathrm{Pa}$ & tibialis-group & Mo \\
\hline 3. P. coadunatus & $\mathrm{Pa}$ & tibialis-group & Ad, Lv, Mo \\
\hline 4. P. constrictus & $\mathrm{Pa}$ & tibialis-group & $\mathrm{Ad}$ \\
\hline 5. P. haemorrhous & $\begin{array}{l}\text { Af, } \mathrm{N}, \mathrm{Nt}, \\
\text { Or, } \mathrm{Pa}\end{array}$ & tibialis-group & Ad, Lv, Mo \\
\hline 6. P. jozanus & $\mathrm{Pa}$ & unplaced & Not considered \\
\hline 7. P. politus & $\mathrm{Au}, \mathrm{Or}, \mathrm{Pa}$ & tibialis-group & Mo \\
\hline 8. P. tibialis & $\mathrm{Pa}$ & tibialis-group & Ad, Lv, Mo \\
\hline $\begin{array}{l}\text { P. goeldlini } \\
\text { Thompson }\end{array}$ & Or & $\begin{array}{l}\text { longiventris- } \\
\text { group }\end{array}$ & Mo \\
\hline P. minutus Hull & Af & $\begin{array}{l}\text { longiventris- } \\
\text { group }\end{array}$ & Mo \\
\hline
\end{tabular}

nite (traditionally called paramere, see Sinclair, 2000) are the main morphological characters used to separate West Palaearctic Pandasyopthalmus species (see Vujic et al., 1998). However, in the tibialis-group in particular, determination is extremely difficult because of the minute morphological differences between some species (e.g. Doczkal, 1996) and the high levels of intra-specific variability (Vockeroth, 1986). Thus, the figures that appear in early monographs must be carefully viewed to determine the shape of the postgonite [e.g., a ventrally pointed hypandrium in some species in lateral view in Goeldlin de Tiefenau (1976, p. 87) does not exist in the same lateral view in other papers, e.g. Vujic et al., 1998]. The most valuable and useful character for identifying most of the species of this group is the shape of postgonites, the patterns of sclerotised and membraneous areas and the arrangement of microtrichia on their inner surfaces (Claussen \& Weipert, 2004). Females can sometimes be associated with males on the basis of distribution, but most remain undescribed because they are inseparable (Goeldlin de Tiefenau, 1976).

Preimaginal stages of the majority of Pandasyopthalmus species have not been described, and only a few papers on $P$. haemorrhous and $P$. tibialis are available. Existing accounts are incomplete (e.g. lack descriptions of larval chaetotaxy) or confusing and do not allow species to be distinguished (Metcalf, 1911, 1913; Campbell \& Davidson, 1924; Heiss, 1938; Dixon, 1960). A very brief description of the eggs of $P$. tibialis is given in Daminova (1975). The general description of Paragus larvae from Rotheray \& Gilbert (1989) and Rotheray (1993) is based on P. haemorrhous. The puparium of this species is described and illustrated by Goeldlin de Tiefenau (1974) based on a single specimen. In this paper, a review of the morphology of the larvae of Pan- dasyopthalmus species, including novel features of the head chaetotaxy of Syrphidae larvae, is presented.

Recently, molecular characters were successfully used for resolving species- and generic-level relationships in the Syrphoidea (e.g., Cheng et al., 2000; Skevington \& Yeates, 2000; Ståhls et al., 2003). Mitochondrial coding genes as well as nuclear non-coding regions are fast evolving and have proven informative in Diptera, even at the intraspecific level (e.g. Paskewitz et al., 1993; Simon et al., 1994; Sharpe et al., 2000). The 3' end of the mitochondrial gene cytochrome $c$ oxidase subunit I (COI) was informative for a species-level phylogeny of the syrphid genus Cheilosia, and is highly conservative within species (Ståhls \& Nyblom, 2000). This gene was also used to resolve species relationships in other syrphid genera (Pérez-Bañón et al., 2003a; Ståhls et al., 2003). Hebert et al. (2003a) have proposed a DNA barcoding system for animal life based on species-specific unique sequences of a $650 \mathrm{bp}$ fragment of the 5'-end of cytochrome c oxidase subunit $1(C O I)$. Thus, because this gene was informative both at intra- and interspecific levels in closely related species it was used in this study. The nuclear non-coding ITS2 (internal transcribed spacer two) is a rapidly evolving region and has proved useful for comparing closely related insect species, subspecies or populations (e.g. Paskewitz et al., 1993; Harris \& Crandall, 2000; Alvarez \& Hoy, 2002; Leo \& Barker, 2002). We chose to elucidate the phylogenetic information in this region of the high levels of intra-individual variation described for this region in other insects.

The West Palaearctic tibialis-group species of subgenus Pandasyopthalmus are very similar morphologically and separable in most cases only by structural differences in the male terminalia, especially crucial for species recognition is the morphology of the postgonite. As the morphological differences between the species are small and gradual, establishing discrete groups for each species is difficult. This prompted us to employ a diverse array of new larval characters and molecular evidence to elucidate the status of these taxa.

\section{MATERIALS AND METHODS}

\section{Morphological studies}

To study the variability of the different taxa, the existing taxonomic literature on Pandasyopthalmus species was reviewed and most of the West Palaearctic tibialis-group species examined, especially the numerous specimens of $P$. haemorrhous and $P$. tibialis in the entomological collection of Universidad de Alicante, Spain (Table 2). As type specimens were not consulted, materials from several collections were examined (i.e., Museo Nacional de Ciencias Naturales de Madrid, Spain; Finnish Museum of Natural History, Helsinki, Finland; British Museum of Natural History, London, UK, and University of Novi Sad, Serbia \& Montenegro) to confirm species identification of males. The specimens were mainly from the Mediterranean area, but material from Northern and Central Europe, Macronesia, Nearctic and Afrotropical regions was also studied.

While some descriptions of female morphology exist in the literature, a reliable key is lacking and most female forms remain undescribed because they cannot be satisfactorily separated. Speight \& Chandler (1995) indicated that males and 
TABLE 2. Voucher information for the morphological studies. Each specimen is identified by a unique code; $m=$ male, $f=$ female. The specimens are deposited in the entomological collection of Universidad de Alicante (CEUA), Spain.

\begin{tabular}{|c|c|c|c|}
\hline Species & Adults & Larvae & Puparia \\
\hline P. coadunatus & $\begin{array}{l}\text { GF-1 (f), GF-2 (f), GF-3 (m), GF-4 (m), S29 } \\
(\mathrm{m}), \text { S37 (m), S38 (m), ML-2 (m), ML-3 (m), } \\
\text { ML-4 (m) }\end{array}$ & Unknown & GF-4 (m) \\
\hline P. constrictus & $\begin{array}{l}\text { PC-1 (m), PC-2 (f), PC-3 (m), PC-4 (m), } \\
\text { PC-5 (f), PC-6 (m) }\end{array}$ & Unknown & Unknown \\
\hline P. haemorrhous & $\begin{array}{l}\text { T-653 (f), PM-2 (m), MA-1 (m), MA-2 (f), } \\
\text { MA-3 (f), OR-537 (f), ST5113 (m), CP-3 (f), } \\
\text { MA-14 (f), MA-15 (f), MA-16 (f), MA-17 (f), } \\
\text { MA-18 (f), MA-19 (m), MA-183 (m), } \\
\text { MA-213 (m), MA-802 (m), MA809 (m), } \\
\text { ST2980 (m), S115 (m) S20 (m), S26 (m), S27 } \\
\text { (m), S48 (m), S98 (m), S99 (m), S251 (m), } \\
\text { S67 (m), S113 (m), SXXX (m), SXXX (m) }\end{array}$ & & $\begin{array}{l}\text { ST5101 (m), ST5175 (m), ST5056 } \\
(\mathrm{m}), \text { ST5051 (m), ST5103 (m), } \\
\text { ST2944 (m), ST2951 (m), ST3465 } \\
(\mathrm{m}), \text { ST5393 (m), ST5048 (m), } \\
\text { ST3527 (f), ST4167 (f), ST3507 (f), } \\
\text { ST3517 (f), ST3520 (f), ST4151 (f), } \\
\text { ST4140 (f), ST3527 (f), ST2948 (f), } \\
\text { ST2970 (f), ST4166 (f) }\end{array}$ \\
\hline P. politus & $\begin{array}{l}\text { S93 (m), S95 (m), S268 (m), GF-5 (f), GF-6 } \\
\text { (f), GF-7 (f) }\end{array}$ & Unknown & Unknown \\
\hline P. tibialis & $\begin{array}{l}\text { GF-8 (f), GF-9 (f), GF10 (f), PM-3 (m), MA- } \\
672(\mathrm{~m}), \text { MA-4 (m), MA-5 (m), S1777 (m), } \\
\text { CP-1 (m), CP-2 (m), MA-6 (m), MB-1 (m), } \\
\text { IR-1 (m), MA-7 (f), MA8 (f), MA-9 (f), } \\
\text { MA-10 (f), MA-11 (f), MA-12 (f), MA-13 (f), } \\
\text { S28 (m), S35 (m), S36 (m), S49 (m), S52 (m), } \\
\text { S326 (m), S96 (m) }\end{array}$ & & $\begin{array}{l}\text { ST3486 (m), ST580 (m), ST2974 } \\
(\mathrm{m}), \text { ST2953 (m), ST2961 (m), } \\
\text { ST2969 (m), SA-65-e (m), SA-65-a } \\
(\mathrm{m}), \text { SA-54-a (m), SA-66-c (m), } \\
\text { ST515 (f), ST2979 (f), ST2942 (f), } \\
\text { ST595 (f), ST518 (f), ST581 (f), } \\
\text { ST2919 (f), ST2975 (f), ST3445 (f), } \\
\text { SA-91-d (f) }\end{array}$ \\
\hline $\begin{array}{l}\text { Pandasyopthalmus spp. } \\
\text { (West Palaearctic } \\
\text { larvae) }\end{array}$ & - & $\begin{array}{l}\text { LP-100, LP-101, LP- } \\
\text { 102, LP-103, LP-104, } \\
\text { LP-105, LP-107, LP- } \\
\text { 108, LP-109, LP-110 }\end{array}$ & - \\
\hline
\end{tabular}

females of $P$. haemorrhous possess abdominal transverse bands of black, reclined setae on tergites 2, 3 and often 4 , and that these are absent in P. tibialis. Unfortunately, females of other Pandasyopthalmus species cannot be separated with confidence using these features. In spite of this, females identified as $P$. coadunatus and $P$. constrictus, from localities where these taxa were clearly more abundant than other species of the tibialisgroup, were also studied. Illustrations of female terminalia were made using preserved material examined under a binocular microscope (Leica Wild M8), with an eyepiece micrometre and FSA 25 PE drawing tube.

The preimaginal morphology of $P$. coadunatus, $P$. haemorrhous and P. tibialis (Table 2) was also studied. Field-collected larvae from Alicante Province (Villena), Spain (30S XH 87 UTM) (P. haemorrhous, P. tibialis; larval Figs 3A, B, 4A-D, $5 \mathrm{~A}-\mathrm{D}, 7 \mathrm{~A}-\mathrm{D})$, and from Madeira Island, Portugal (P. coadunatus), were fed with aphids from the same colony from which they were collected. Rearing took place in a growth chamber at $16-22^{\circ} \mathrm{C}, 80 \pm 5 \% \mathrm{r}$. h. and a constant photo period of 15L : 9D. Pupae were isolated in individual Petri dishes and inspected daily until the adults emerged.

Larvae selected for preservation were third stage and had emptied the hindgut. For permanent preservation, larvae were killed by immersion in cold water and heated slowly for about four minutes to extend them. To study the prothorax and metathorax morphology, these parts were extended by lightly pressing the first abdominal segments. Afterwards, they were preserved in $70 \%$ alcohol. The cephalopharyngeal skeleton was removed from the leading ventral edge of the interior of the puparium and placed in warm $10 \%$ potassium hydroxide $(\mathrm{KOH})$ for 3-4 min. The larvae were then immediately washed in distilled water and preserved in pure glycerine prior to examination.
Descriptions are based on preserved specimens with larval characters checked against living specimens (or slides) to minimise errors due to preservation. Measurements of dimensions (mean \pm standard error) were made on preserved material using a binocular microscope. The photographs were taken with a scanning electron microscope (SEM; JEOL 840, operated at 20 $\mathrm{kV})$.

Terminology used for descriptions of the larvae and pupae follows Hartley $(1961,1963)$ and Thompson \& Rotheray (1998). The positions of the sensilla were numbered sequentially from the dorsal to the ventral surface for each segment (Rotheray, 1991). In addition, included in parentheses is the morphological terminology used by Courtney et al. (2000) and Sinclair (2000), according to the current understanding of the homology of dipteran larvae and male terminalia, respectively.

\section{Molecular studies}

DNA was extracted from frozen specimens or from specimens preserved in $70-95 \%$ alcohol. The biological data of specimens and GenBank accession numbers for sequence fragments are listed in Table 3. Male genitalia were conserved for the purpose of morphological studies. DNA was extracted from single individuals by crushing and incubation at $+37^{\circ} \mathrm{C}$ for approximately $18 \mathrm{~h}$ in Proteinase $\mathrm{K}(20 \mathrm{mg} / \mathrm{ml})$, followed by $2 \mathrm{M}$ sodium acetate/ethanol precipitation $(96 \%)$ and re-suspension in $50-100$ $\mu \mathrm{l}$ of ultra-pure water.

PCR's were carried out in $50 \mu \mathrm{l}$ reactions containing $2 \mu \mathrm{l}$ DNA extract, $2 \mu \mathrm{l}$ of each primer (at $10 \mathrm{pmol} / \mu \mathrm{l}$ ), $0.25 \mu \mathrm{l}$ of Amplitaq DNA polymerase $(5 \mathrm{U} / \mu \mathrm{l}), 4 \mu \mathrm{l} 2.5 \mathrm{mM} \mathrm{MgCl} 2,5 \mu \mathrm{l}$ 10X Buffer II (Applied Biosystems, Foster City, CA, USA) and $4 \mu 1200 \mathrm{mM}$ dNTP (GeneAmp) and water, or in $25 \mu 1$ reactions using half amounts. Thermocycler conditions were initial denaturing at $95^{\circ} \mathrm{C} 2 \mathrm{~min}, 29$ cycles of $30 \mathrm{~s}$ denaturing at $94^{\circ} \mathrm{C}, 30 \mathrm{~s}$ 
TABLE 3. Taxonomic list, number of individuals, stage/reference, source, and GenBank accession numbers of specimens used in the molecular analysis. Notes. One sequence from each geographical origin was submitted to GenBank [between brackets] $(*)$ refers to ITS2 sequences, no symbols are COI sequences. Male genitalia and voucher specimens are conserved in the entomological collection of University of Alicante (CEUA), Spain. NS means COI not submitted.

\begin{tabular}{|c|c|c|c|}
\hline Species & Stage / ref & Source of specimens & GenBank nos \\
\hline Pipiza sp. (Outgroup) & 1 male / S0 & Sweden, Uppland, & AY174459 [S0] \\
\hline \multicolumn{4}{|c|}{ Sg. Pandasyopthalmus (tibialis group) } \\
\hline P. ascoensis & 1 male / Y3 & Sardinia, 2003 & COI \& *ITS2 submitted \\
\hline P. coadunatus & $\begin{array}{l}3 \text { males / S29-S37-S38; } 2 \\
\text { females/ S333-S334-S336 }\end{array}$ & $\begin{array}{l}\text { Malta, Msida, } 1999 \\
\text { AY174467 [S38] }\end{array}$ & $\begin{array}{l}\text { *AY217732 [S333] } \\
\text { *AY217733 [S37] } \\
\text { *AY217734 [S336] } \\
\text { *ITS2 submitted [S334] }\end{array}$ \\
\hline P. haemorrhous & $\begin{array}{l}4 \text { males } / \text { S20-S26-S27-S48; } \\
1 \text { female/S14 }\end{array}$ & Spain, Alicante, 2000 & $\begin{array}{l}\text { AY174470 [S48] } \\
\text { *ITS2 submitted [S14] }\end{array}$ \\
\hline P. haemorrhous & 2 males / S98-S99 & $\begin{array}{l}\text { Greece, Lesbos island, } \\
2001\end{array}$ & $\begin{array}{l}\text { AY174479 [S98] } \\
\text { *AY217736 [S98] } \\
\text { *AY217737 [S99] }\end{array}$ \\
\hline P. haemorrhous & 1 male / S251 & Finland, Strömfors, 2002 & $\begin{array}{l}\text { AY174466 [S251] } \\
* A Y 217730[\mathrm{~S} 251]\end{array}$ \\
\hline P. haemorrhous & 1 male / S67 & $\begin{array}{l}\text { Czech Republic, Rokytno, } \\
2000\end{array}$ & $\begin{array}{l}\text { N.S. *Sequence from LCO } \\
\text { primer only }\end{array}$ \\
\hline P. haemorrhous & 2 males / S113-S115 & $\begin{array}{l}\text { South Africa, Koop SV } \\
\text { Drift, } 2000\end{array}$ & AY174471 [S115] \\
\hline P. haemorrhous & 2 males / S308-S310 & Nearctic, 1999 & AY275521 [S308] \\
\hline P. politus & 1 male / S91 & $\begin{array}{l}\text { Australia, Daintree } \\
\text { National Park, } 1999\end{array}$ & AY174460 [S91] \\
\hline P. nr politus & 1 male / S95 & Thailand, 2000 & AY174461 [S95] \\
\hline P. tibialis & $\begin{array}{l}5 \text { males / S28-S35-S36-S49- } \\
\text { S52; } 1 \text { female / S03 }\end{array}$ & $\begin{array}{l}\text { Spain, Alicante, Teruel, } \\
2000\end{array}$ & $\begin{array}{l}\text { AY174465 [S52] } \\
\text { *ITS2 submitted [S03] }\end{array}$ \\
\hline P. tibialis & 1 male / S96 & $\begin{array}{l}\text { Greece, Lesbos island, } \\
2001\end{array}$ & $\begin{array}{l}\text { AY174468 [S96] } \\
* \text { AY217735 [S96] }\end{array}$ \\
\hline P. tibialis & 1 male / S326 & Finland, Eno, 2002 & $\begin{array}{l}\text { COI submitted }[\mathrm{S} 326] \\
* \text { AY217731 }[\mathrm{S} 326]\end{array}$ \\
\hline \multicolumn{4}{|c|}{ Sg. Pandasyopthalmus (longiventris-group) } \\
\hline P. nr goeldlini & 1 female / S275 & West Malaysia, 2001 & AY174463 [S275] \\
\hline P. nr minutus & 1 female / S286 & Tanzania, 2001 & AY275522 [S286] \\
\hline \multicolumn{4}{|l|}{ Subgenus Paragus } \\
\hline P. bicolor Fabricius & 1 male / S110 & Turkey, Sivas, 2001 & AY174462 [S110] \\
\hline P. quadrifasciatus Meigen & 1 male / S112 & Turkey, Sivas, 2001 & AY174464 [S112] \\
\hline
\end{tabular}

annealing at $49^{\circ} \mathrm{C}, 2$ min extension at $72^{\circ} \mathrm{C}$, followed by a final extension of $8 \mathrm{~min}$ at $72^{\circ} \mathrm{C}$. PCR products were purified using the GFX PCR Purification Kit (Amersham Biotech, Little Chalfont, UK) and then sequenced (with the PCR primers) in both directions using the Big Dye Terminator Cycle Sequencing Kit (Applied Biosystems) at one-fourth of the recommended volumes on ABI PRISM 377 and ABI 310 automated DNA sequencers. The universally conserved primers used for amplifying and sequencing the COI and ITS2 fragments are listed in Table 4. Generally, the COI fragment was amplified using the forward primer LCO-S-1490 and the reverse primer TL2-N3014, and sequencing was performed with amplification primers, the internal forward primer C1-S-1718 and the reverse primer C1-J-2183. The homologous COI sequence fragment could also be obtained by using primer combinations LCO-S$1490+$ C1-J-2183 and C1-S-1718 + TL2-N-3014 and the above PCR and sequencing conditions. The ITS2 fragment was amplified and sequenced using the same primers. The sequences were edited for base-calling errors and assembled using Sequence Navigator $^{\mathrm{TM}}$ (version 1.01, Applied Biosystems).

TABLE 4. Primers used for amplifying and sequencing the COI and ITS2 fragments.

\begin{tabular}{lll}
\hline Primer & Sequence & Source \\
\hline LCO-S-1490 & 5'-GGTCAACAAATCATAAAGATATATTGG-3' & Folmer et al., 1994 \\
TL2-N-3014 & 5'-TCCAATGCACTAATCTGCCATATTA-3' & Folmer et al., 1994 \\
C1-S-1718 & 5'-GGAGGATTTGGAATTGATTAGTTCC-3' & Simon et al., 1994 \\
C1-J-2183 & 5'-CAACATTTATTTTGATTTTTGG-3' & Simon et al., 1994 \\
ITS2A (f) & 5'-TGTGAACTGCAGGACACAT-3' & Beebe \& Saul, 1995 \\
ITS2B (r) & 5'-TATGCTTAAATTCAGGGGGT-3' & Beebe \& Saul, 1995 \\
\hline
\end{tabular}




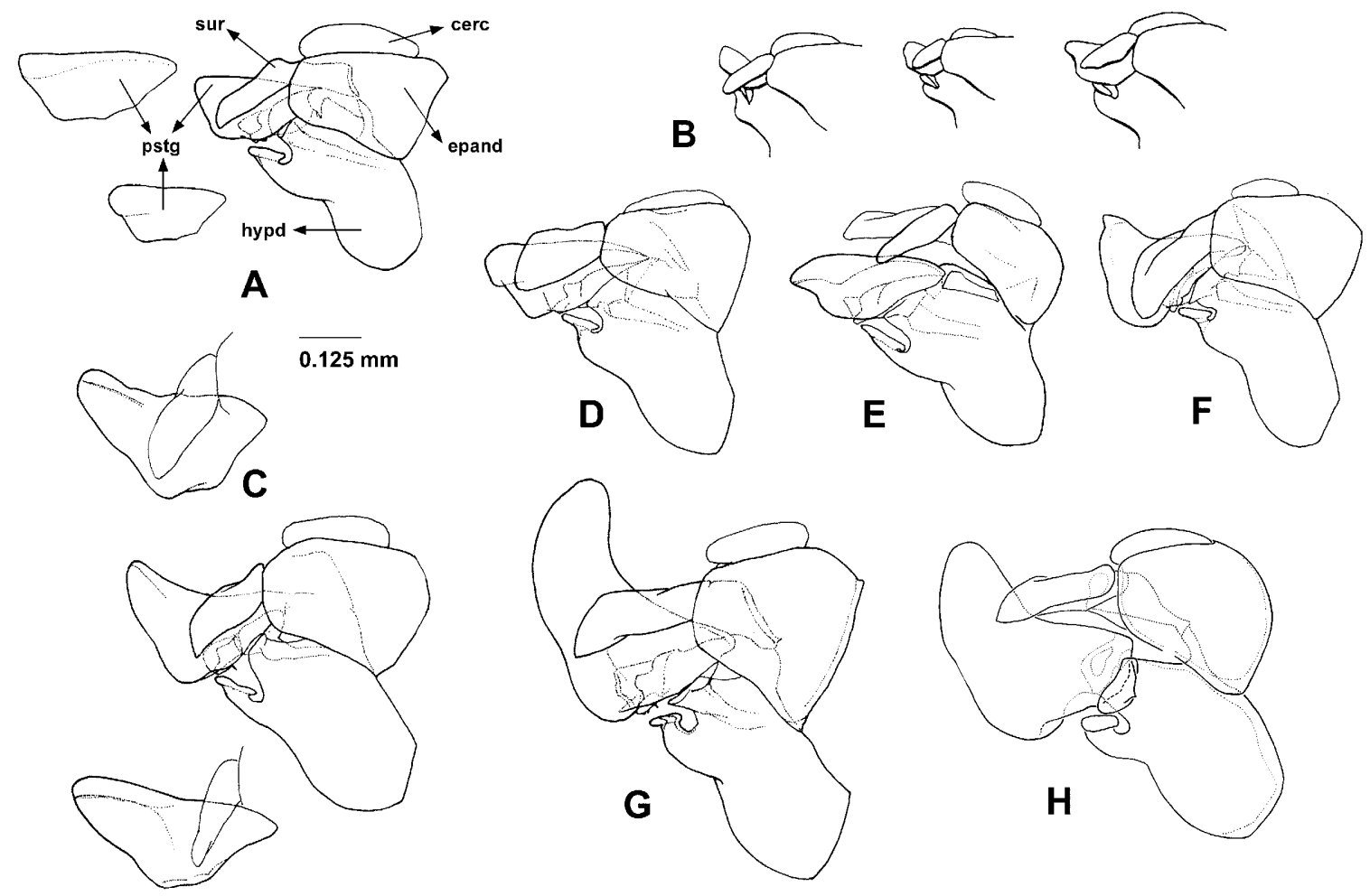

Fig. 1. Male genitalia of some West Palaearctic tibialis-group species, showing variability in the structure of the postgonites (lateral view). A, B - P. haemorrhous; $\mathrm{C}-P$. constrictus; $\mathrm{D}-P$. albipes; $\mathrm{E}-P$. coadunatus; $\mathrm{F}-P$. ascoensis; $\mathrm{G}-P$. tibialis (Mediterranean); H - P. tibialis (Germany). Adapted from: A, C, D, E, F, G: Vujic et al., 1998; B: Speight, 1978; H: Doczkal, 1996. (No scale available for drawing B and $\mathrm{H})$. Abbreviations: cerc - cercus, epand - epandrium, hypd - hypandrium, sur - surstylus, pstg postgonite (= paramere).

Altogether 1128 mitochondrial nucleotide characters were obtained, spanning nucleotide positions 1563 to 2691 of the mtDNA COI gene (numbering is based on Drosophila yakuba sequence; Clary \& Wolstenholme, 1985). Nucleotide sequences of the COI gene of multiple specimens of both groups of the subgenus Pandasyopthalmus (tibialis- and longiventris-groups), and a few species of the subgenus Paragus s. str., were produced (see Table 3). However, this study's main goal was to assess the taxonomic status of the West Palaearctic tibialisgroup of species, not to explore the phylogenetic relationships of these species and/or subgenera of Paragus. The acquired sequence data, therefore, was used mainly to contrast the uncorrected pairwise sequence divergences of the sequenced taxa and explore the levels of sequence variation. As the sequences were mainly used to compare closely related species, only uncorrected sequence divergences were examined (as \% sequence differences), simply because any correction algorithm will affect the $p$ values when sequence divergences are $>5 \%$. ITS2 sequences for a set of twelve specimens of the West Palaearctic tibialis-group species, chosen to represent different morphotypes (e.g., $P$. ascoensis, $P$. coadunatus, $P$. haemorrhous, $P$. tibialis taxa) and different geographical regions, were produced (see Table 3).

Using the COI sequences of altogether 16 terminals, a parsimony analysis with equal weights was performed using the computer program Nona version 2.0 (Goloboff, 1993), spawned from WinClada version 1.00.08 (Nixon, 2002), to study the phylogenetic relationships between the included taxa. Bootstrap values (branch support) were obtained with WinClada using 500 replicates.

\section{RESULTS}

\section{Adult morphology}

Our examination of the male genitalia in a large series of the most widely distributed Pandasyopthalmus species, $P$. haemorrhous, confirmed the great variability in the shape and size of the postgonites, which is reported in the literature (see Fig. 1A, B, C). These differences are not correlated with the size of the adult fly and occur typically at the intraspecific level.

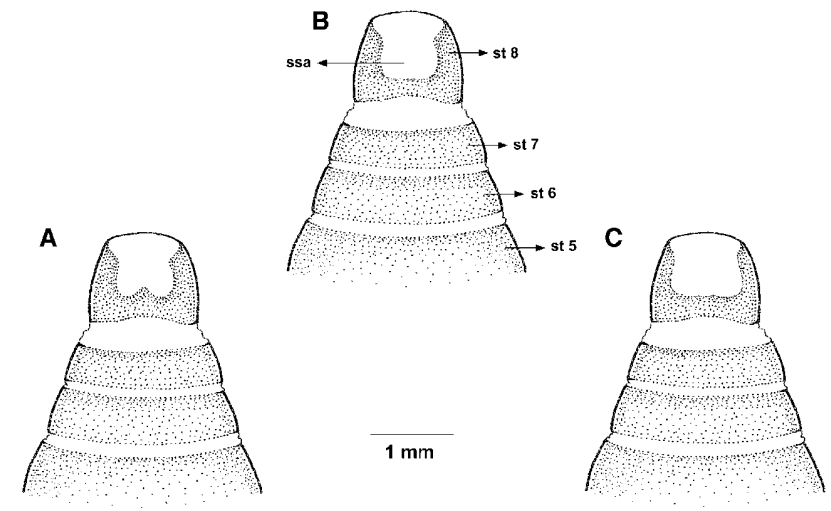

Fig. 2. Female terminalia of some West Palaearctic tibialisgroup species. Ventral view of sternite 8 (st 8 ) showing the shape and size of the distal slightly sclerotized area (ssa). A $-P$. haemorrhous; B - P. coadunatus; C - P. tibialis. Epiproct and cerci are omitted. 


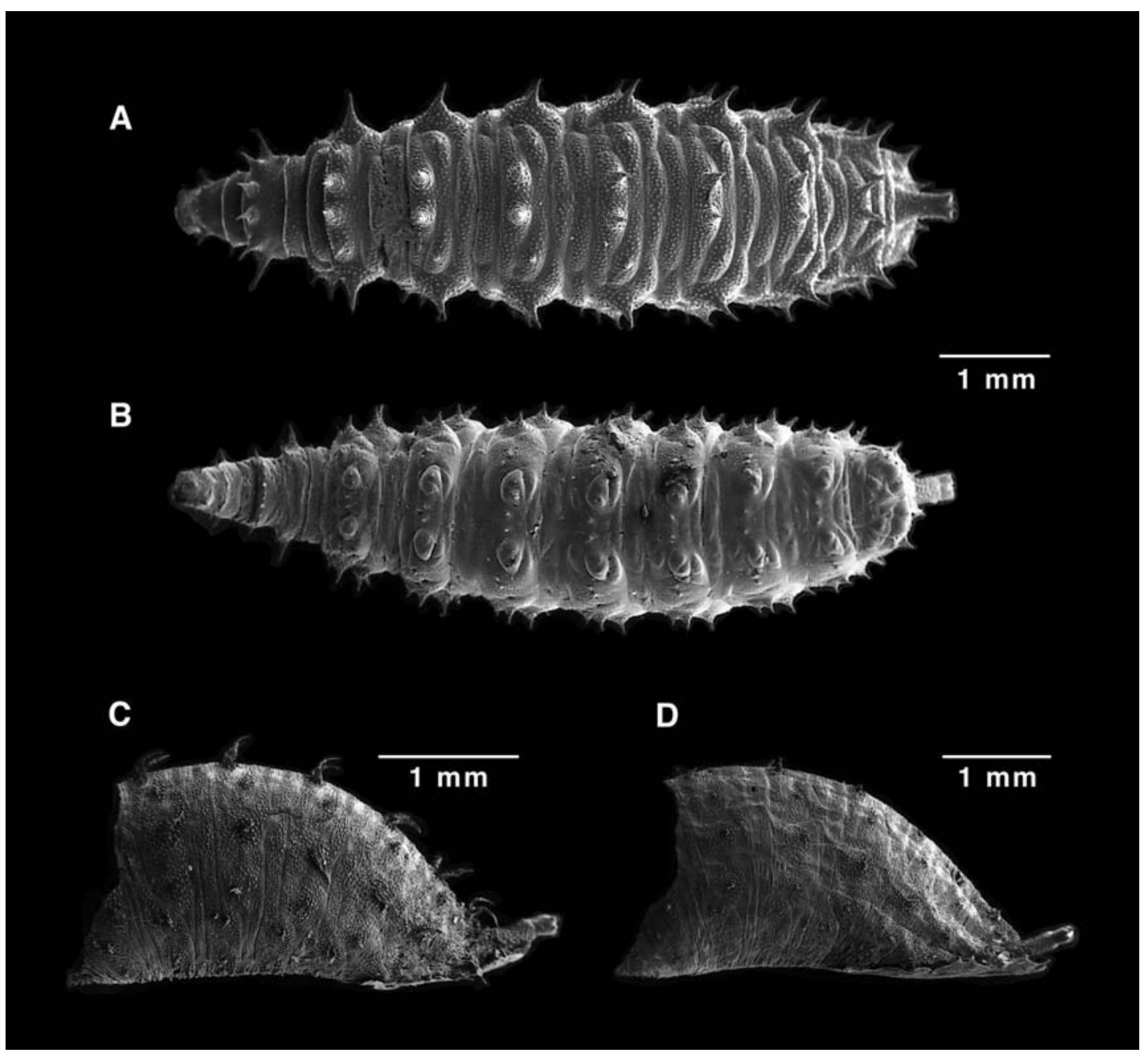

Fig. 3. Scanning electron micrographs of the immature stages of West Palaearctic tibialis-group species. A and B: larvae, dorsal view (A), ventral view (B); C and D: lateral view of puparium, P. haemorrhous (C), P. tibialis (D).

In the case of $P$. tibialis, small differences in the shape and size of postgonites are apparent when descriptions of material from different countries are compared. This variation occurs in other species of the Palaearctic tibialis-group with more restricted distributions, such as P. constrictus (Fig. 1, D-E).

The postabdomen of females of the exemplars studied (see Table 2) was usually entirely black, with tergites and sternites 6,7 and 8 telescoped within the preceding sclerites. No dorsal sclerites beyond tergite 8 were found, cerci occupy a mid-dorsal position; sub-anal plate present. The females of $P$. haemorrhous and P. tibialis possess sternite 8 , with a slightly sclerotized distal area of variable form. No intraspecific variability is apparent. However, in $P$. coadunatus the shape and size of this area is of an intermediate form (Fig. 2).

The abdominal transverse bands of black and reclined setae in $P$. haemorrhous are also present in females of $P$. coadunatus. However, this character is highly variable in males of $P$. coadunatus as well as females and males of $P$. tibialis and $P$. constrictus. These taxa either completely lack these setae, have only whitish and erect hairs, or have a small group of black setae in the middle of some tergites, which never form a continuous band. A marked variability was observed in the abdominal colour pattern of both sexes of $P$. haemorrhous and $P$. tibialis. The range is from entirely black to tergites 3,4 and 5 being reddish, with all possible intermediates. Our speci-

TABLE 4. Primers used for amplifying and sequencing the COI and ITS2 fragments.

\begin{tabular}{lll}
\hline Primer & Sequence & Source \\
\hline LCO-S-1490 & 5'-GGTCAACAAATCATAAAGATATATTGG-3' & Folmer et al., 1994 \\
TL2-N-3014 & 5'-TCCAATGCACTAATCTGCCATATTA-3' & Folmer et al., 1994 \\
C1-S-1718 & 5'-GGAGGATTTGGAATTGATTAGTTCC-3' & Simon et al., 1994 \\
C1-J-2183 & 5'-CAACATTTATTTTGATTTTTGG-3' & Simon et al., 1994 \\
ITS2A (f) & 5'-TGTGAACTGCAGGACACAT-3' & Beebe \& Saul, 1995 \\
ITS2B (r) & 5'-TATGCTTAAATTCAGGGGGT-3' & Beebe \& Saul, 1995 \\
\hline
\end{tabular}



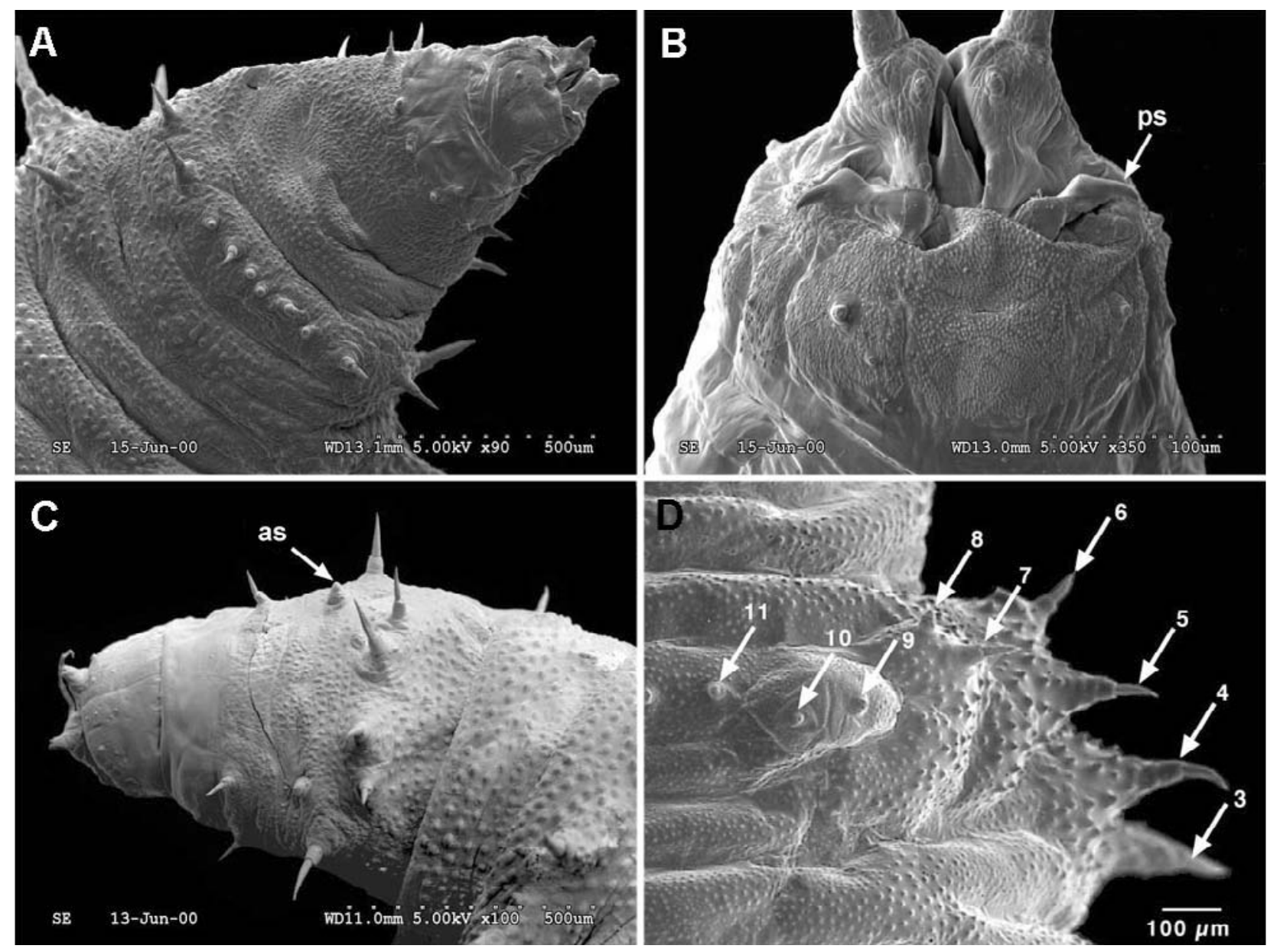

Fig. 4. Scanning electron micrographs of West Palaearctic tibialis-group larvae. A - head and thorax, ventral view; B - head and prothorax (ps - prothoracic sclerites); C - head and thorax, dorsal view (as - anterior spiracles); D - detail of locomotory prominences and ventral chaetotaxy (numbers) of the first abdominal segment.

mens of $P$. coadunatus had entirely black abdomens, but in the literature, other forms are also described (Goeldlin de Tiefenau, 1976).

\section{Immature morphology}

Description of the larvae

Full descriptions of the larval and puparial morphology of all the specimens studied are presented. Some specimens were reared and identified as: $P$. coadunatus, $P$. haemorrhous or P. tibialis (see methodology).

Overall appearance. Oval in cross-section with a flattened ventral surface, strongly tapering anteriorly and slightly tapering posteriorly (Fig. 3). Dorsal habitus serrate owing to fleshy lateral projections. Cuticle translucent when alive, creamy to dark brown after fixation. Colour pattern extremely variable, pearly white to mottled white or brown to reddish-brown. Dorsal body surface covered with dome-shaped and densely aggregated papillae, which are smaller on the ventral surface (Fig. 4A). Dorsal sensilla borne on fleshy projections (Fig. 3A). The main diagnostic feature of this taxon is the shape of posterior spiracle: at least twice as long as broad. Length 6.7 $\pm 0.17 \mathrm{~mm}$, maximum width $2.18 \pm 0.034 \mathrm{~mm}(n=10)$.
Head (pseudocephalon). The head is very reduced. Mouth hooks adapted for piercing-feeding (Hartley, 1963) with the distinctive features of predacious syrphid larvae. Antenno-maxillae organs well-developed. Ultrastructure in SEM photos highlighted the occurrence of many sensilla on top of the antenno-maxillae organs, mainly chemoreceptors (styloconics and basiconics), but also mechanoreceptors (placoids), as in other aphidophagous larvae (Ngamo Tinkeu \& Hance, 2002).

Thorax. Anterolateral margin of the prothorax with a pair of black triangular pointed sclerites (ps) (Fig. 4B). Vestiture on prothorax above $4^{\text {th }}$ sensilla of mesothorax is reduced, giving the integument a clear shiny appearance. Anterior fold of the prothorax with longitudinal grooves and a ring (covering $<35 \%$ of dorsal surface and $<50 \%$ of ventral surface) of small, densely aggregated, backwardly directed spicules, which become progressively scarcer posteriorly (Fig. 4B). A second ring of small spicules appears immediately anterior to $4^{\text {th }}$ sensilla of mesothorax. Dorsal surface of the prothorax with anterior spiracles (as) sclerotized and short (Fig. 4C).

Abdomen. Locomotory prominences small, without crochets or musculature (Fig. 4D), 7 abdominal pairs on segments 1-7 (Fig. 3B). Anal segment (anal division) bi- 

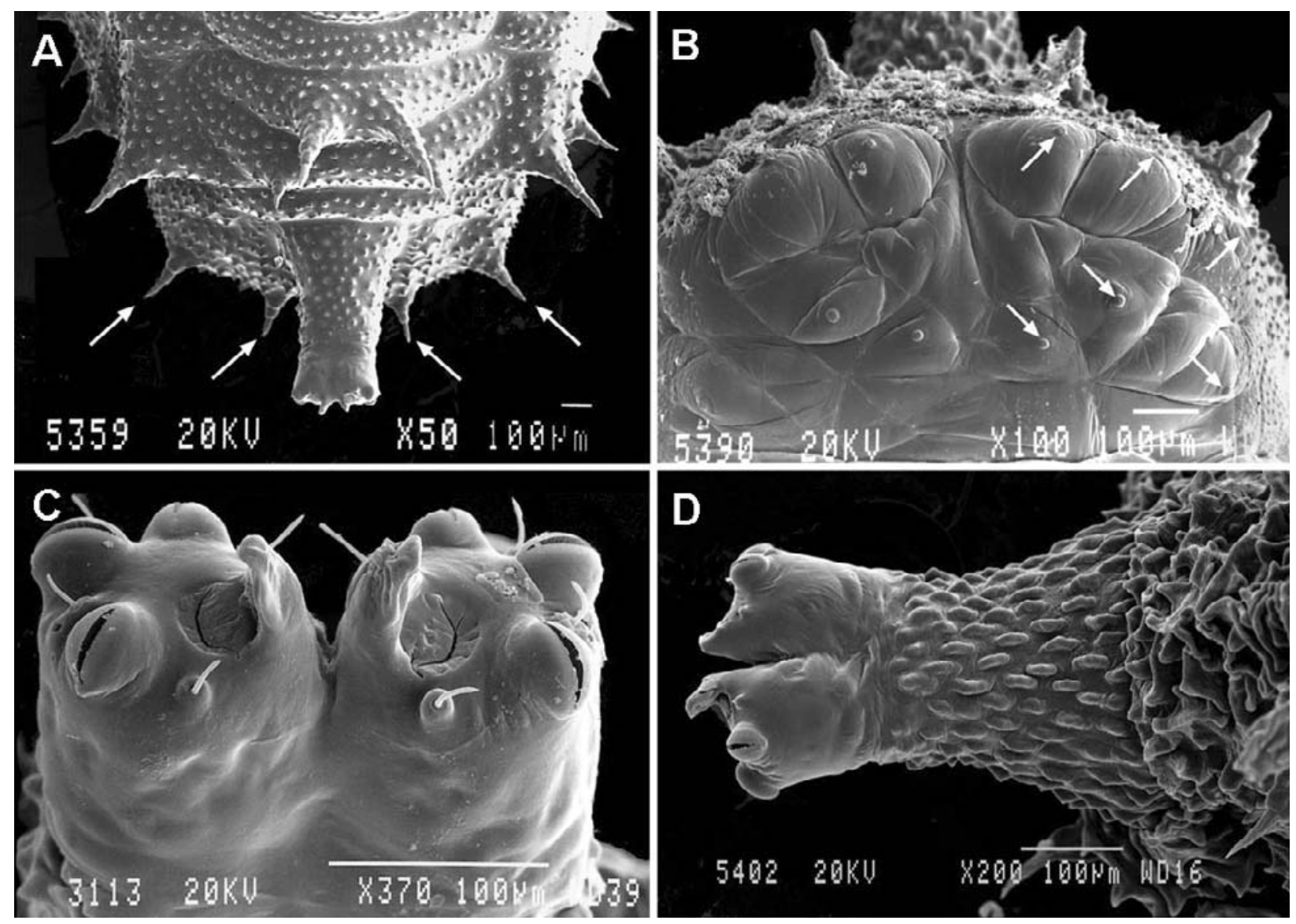

Fig. 5. Scanning electron micrographs of anal segment and posterior spiracle (ps) of West Palaearctic tibialis-group larvae. A-B, anal segment and chaetotaxy (arrows indicate the position of sensilla), dorsal view $(2+2$ sensilla) (A), ventral view (sensilla of one side) (B); C - spiracular plates of ps; D - ornamentation of ps, dorsal view.

lobed, with a row of 4 setae behind the posterior spiracle (Fig. 5A). Vestiture on ventral surface of anal segment is absent, giving the integument a clear shiny appearance (Fig. 5B). Posterior spiracle (ps): Length $0.48 \pm 0.009$ $\mathrm{mm}$; width: at base $0.30 \pm 0.007 \mathrm{~mm}$, at tip $0.24 \pm 0.003$ $\mathrm{mm} ;(n=10)$. Lustrous, sclerotized and brown in colour. The spiracular plates are separated by a deep median groove. Dorsal spurs pointed and V-shaped, about as long as the length of the spiracular slits (Fig. 5C, D). The spiracular slits are mounted on high carinae, extending about half their length over the sides of the posterior spiracle. Carinae not differentiated in colour from the rest of the ps. Spiracular slits radial and straight, equidistant from each other. Periphery with four pairs of long interspiracular setae (peristigmatal setae) mounted on small cones (Fig. 5C). Surface of ps with a constriction about twothirds of the distance from the base. The basal two-thirds strongly nodulate, beyond this the surface is smoother and polished (Fig. 5D).

Chaetotaxy (Fig. 6). Dorsal and dorsolateral sensilla borne on fleshy projections with one seta. The size of the setae and fleshy projections is variable, setae never longer than the fleshy projections. Head $(\mathrm{H})$ with 2 pairs of sensilla of different sizes above the mouth and below the antenno-maxillae organs (Fig. 7A). Ventral sensilla without accompanying setae or projection, except on the metathorax (Fig. 7B). Prothorax (P) with 11 pairs of sensilla; mesothorax (Ms) with 8 pairs of sensilla; metathorax (Mt) with 9 pairs of sensilla belonging to the pattern of chaetotaxy. One extra pair of sensory organs near sensilla 7 on mesothorax and metathorax (Fig. 7C, D); abdominal segments $1-7$ with 11 pairs (Fig. 4D); anal segment with 8 pairs (Fig. 5B).
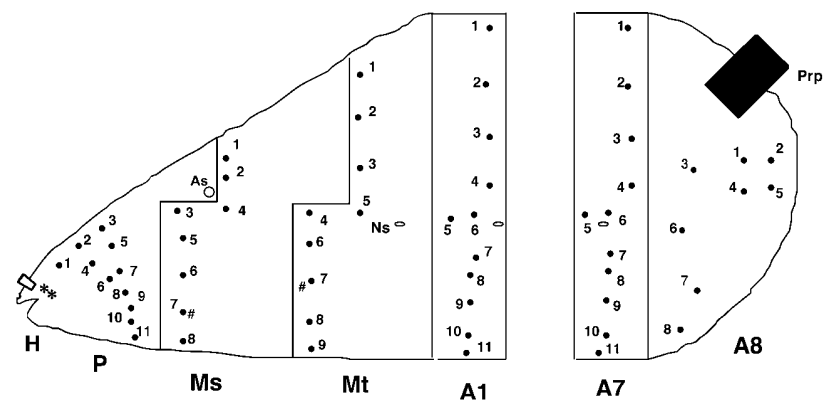

Fig. 6. Map of the chaetotaxy of third instar larvae of the tibialis-group species showing the positions of the groups of sensilla on: $\mathrm{H}$ - head; $\mathrm{P}$ - prothorax; $\mathrm{Ms}$ - mesothorax; $\mathrm{Mt}-$ metathorax; A1, A7 - first and seventh abdominal segments; A8 - posterior end; As - anterior spiracle; Ns - nonfunctional spiracle; Prp - posterior spiracles. Symbols: * - head chaetotaxy; \#extra pair of sensory organs. 

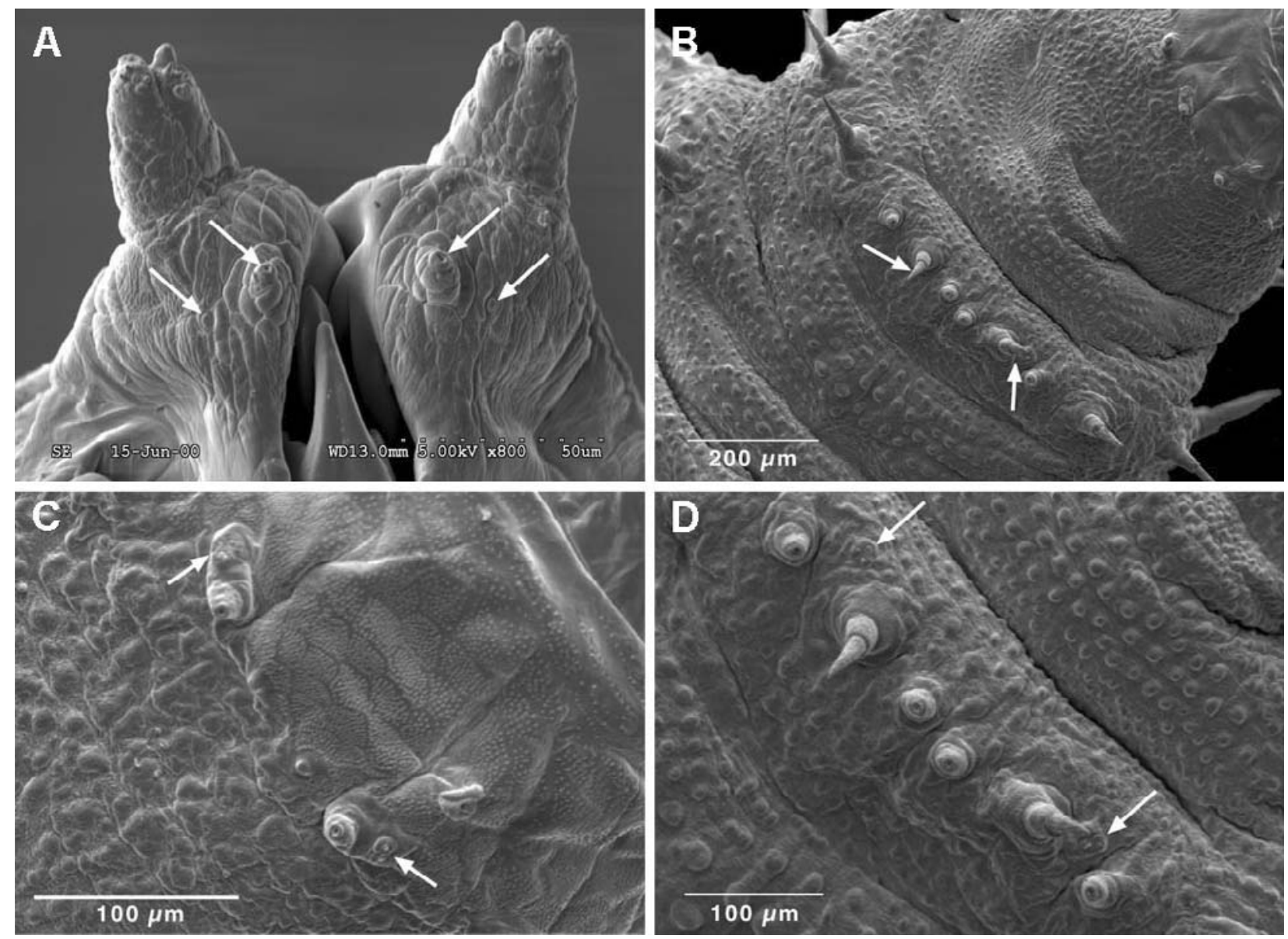

Fig. 7. Scanning electron micrographs of chaetotaxy of the third instar larva of a West Palaearctic tibialis-group species. A - head chaetotaxy; B - ventral sensilla of the metathorax; C and D - extra pair of sensory organs on mesothorax (C) and metathorax (D).

\section{Description of the puparium}

Pear-shaped, sub-cylindrical in cross-section. Anterior extreme truncated, tapered posteriorly and flattened ventrally (Fig. 8). Integument with larval segmentation persisting as transverse folds and wrinkles, segmental sensilla also persisting, except on the ventral surface. Colour varying from cream to dull brown. Larval characters well preserved in the puparium, such as the shape of the posterior spiracles, which are at least twice as long as broad and by which the Palaearctic tibialis-group puparium can be identified. Carinae supporting spiracular slits are black. Length, including posterior spiracles, $3.9 \pm 0.11$ mm, maximum width $1.8 \pm 0.06 \mathrm{~mm}(n=10)$.

Two extremes of variability in the length of sensilla were found. Puparia with long sensilla usually belonged to $P$. haemorrhous (Figs 8A, B, 9A), based on rearing and identifying the adult stages. Puparia with short sensilla were generally $P$. tibialis (Figs 8F, 9D), however, intermediates exist, which are not possible to assign to either species (Figs 8C, D, 9B, C). Paragus coadunatus is intermediate in variability between the two extremes (Fig. 8E).

\section{Molecular studies}

Altogether 1128 mitochondrial nucleotide characters of the mtDNA COI gene were identified. No alignment ambiguity was present. The nucleotide frequencies were biased toward $\mathrm{A}+\mathrm{T}$, averaging $71 \%$. The sequences of the COI gene for West Palaearctic taxa of subgenus Pandasyopthalmus were identical. The number of parsimony informative nucleotide characters for the 15 ingroup terminals used for phylogenetic analysis of the COI gene was 144 . The parsimony analysis resulted in two equally parsimonious trees $(1=355$ steps, $\mathrm{CI}=0.83, \mathrm{RI}=0.82)$. A strict consensus tree with the calculated support values is shown in Fig. 10.

The ITS 2 sequences were obtained for 12 specimens of the West-Palaearctic tibialis-group species (P. ascoensis, $P$. coadunatus, $P$. haemorrhous, $P$. tibialis) (Table 3), chosen to represent different geographic regions and different taxa. The ITS2 sequences were assembled in a manual alignment of about $480 \mathrm{bp}$. Four different haplotypes, variations of a dinucleotide repeat (AT)6-9 (typically interpreted as a microsatellite region), were found in the specimens analyzed (Table 5). Other sequence variation was a few nucleotide changes (indicated in boldface, Table 5). As examples of variation, identical haplotypes were found in one specimen of $P$. haemorrhous from West Greece (Lesbos) and two specimens of $P$. coadunatus from Malta, and another individual of $P$. haemorrhous from West Greece had an identical haplotype with individuals of $P$. tibialis and $P$. haemorrhous from Finland, as did two individuals of $P$. coadunatus from Malta 
TABLE 5. Molecular variation of the variable region of ITS2 sequences of West-Palaearctic Pandasyopthalmus species studied in this paper.

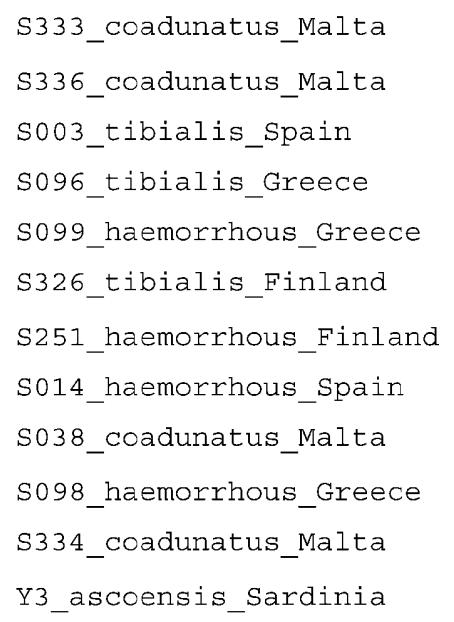

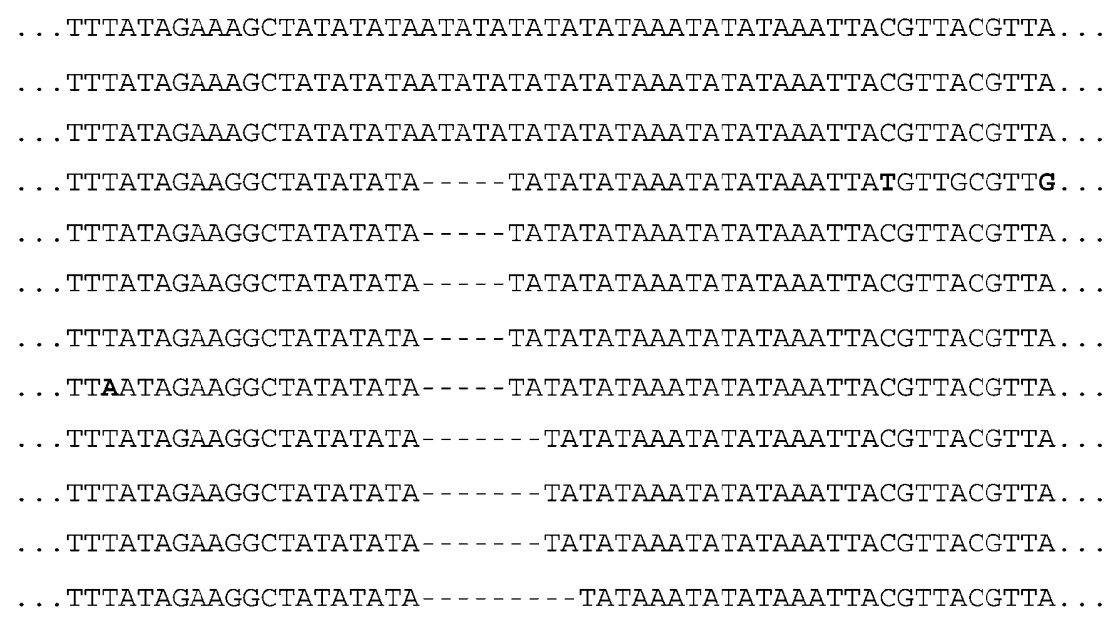

and one specimen of $P$. tibialis from Spain, and a specimen of $P$. tibialis from Greece had a unique haplotype, as did one specimen of $P$ ascoensis from Sardinia and one specimen of $P$. haemorrhous from Spain (Table $5)$.

The uncorrected sequence divergences for the mitochondrial COI within the Pandasyopthalmus lineage varied between $0.0 \%$ and $7.7 \%$ (Table 6). In most cases, the West Palaearctic specimens of tibialis-group taxa $(P$. coadunatus, $P$. haemorrhous and $P$. tibialis) had identical sequences with a maximum of uncorrected pairwise difference of $0.35 \%$ when compared with the Afrotropical sequence of $P$. haemorrhous. However, the Nearctic specimens ( $P$. haemorrhous) sequenced for the COI gene showed an uncorrected pairwise difference of $2.4 \%$ compared with West Palaearctic Pandasyopthalmus. The interspecific divergences in this group varied from $1.1 \%$ to $2.7 \%$ compared with the Australian-Oriental species of the tibialis-group, but this figure increased to $6.6-7.2 \%$ when species of the longiventris-group were considered (Table 6).

The uncorrected pairwise sequence divergences within the studied species of the subgenus Paragus s. str. and the longiventris group were $5.9 \%$ and $1.3 \%$, respectively. The variation between the Pandasyopthalmus and Paragus s. str. was $9.3 \%$ to $11.3 \%$ (Table 6).

\section{DISCUSSION}

\section{Adult morphology}

Stuckenberg (1954) was the first to describe the intraspecific variability in the structure of the male genitalia in some species of the subgenus Pandasyopthalmus. He illustrated the variation in the male genitalia of Paragus

TABlE 6. $\%$ pairwise uncorrected sequence differences. $\mathrm{Au}=$ Australian, Af $=$ Afrotropical, $\mathrm{Ne}=$ Nearctic, $\mathrm{Or}=\mathrm{Oriental}, \mathrm{Pa}=$ Palaearctic. Countries: Finland (Fin), Greece (Gre), Spain (Spa). Species-groups: 1-12 = tibialis-group; 13-14: longiventris-group; 15-16 = Paragus s. str.-group. Note: We also have a sequence from the LCO primer only of P. haemorrhous from the Czech Republic (see Table 3). This fragment does not differ from that of other West Palaearctic taxa analysed.

\begin{tabular}{|c|c|c|c|c|c|c|c|c|c|c|c|c|c|c|c|c|}
\hline Species & 1 & 2 & 3 & 4 & 5 & 6 & 7 & 8 & 9 & 10 & 11 & 12 & 13 & 14 & 15 & 16 \\
\hline $1 P$. ascoensis (Pa) & - & & & & & & & & & & & & & & & \\
\hline 2 P. coadunatus $(\mathrm{Pa})$ & 0.08 & - & & & & & & & & & & & & & & \\
\hline 3 P. haemorrhous (Fin) & 0.08 & 0.00 & - & & & & & & & & & & & & & \\
\hline 4 P. haemorrhous (Gre) & 0.08 & 0.00 & 0.00 & - & & & & & & & & & & & & \\
\hline 5 P. haemorrhous (Spa) & 0.08 & 0.00 & 0.00 & 0.00 & $\cdot$ & & & & & & & & & & & \\
\hline 6 P. tibialis (Fin) & 0.08 & 0.00 & 0.00 & 0.00 & 0.00 & - & & & & & & & & & & \\
\hline 7 P. tibialis (Gre) & 0.17 & 0.08 & 0.08 & 0.08 & 0.08 & 0.08 & - & & & & & & & & & \\
\hline 8 P. tibialis (Spa) & 0.17 & 0.08 & 0.08 & 0.08 & 0.08 & 0.08 & 0.17 & $\cdot$ & & & & & & & & \\
\hline 9 P. haemorrhous (Af) & 0.17 & 0.26 & 0.26 & 0.26 & 0.26 & 0.26 & 0.35 & 0.35 & - & & & & & & & \\
\hline 10 P. haemorrhous $(\mathrm{Ne})$ & 2.23 & 2.23 & 2.23 & 2.23 & 2.23 & 2.23 & 2.37 & 2.38 & 2.23 & - & & & & & & \\
\hline $11 P$. politus (Au) & 2.57 & 2.66 & 2.66 & 2.66 & 2.66 & 2.66 & 2.75 & 2.75 & 2.57 & 2.98 & $\cdot$ & & & & & \\
\hline $12 P . \mathrm{nr}$ politus $(\mathrm{Or})$ & 1.06 & 1.15 & 1.15 & 1.15 & 1.15 & 1.15 & 1.24 & 1.24 & 1.06 & 2.42 & 2.39 & - & & & & \\
\hline $13 P . \mathrm{nr}$ goeldlini (Or) & 7.09 & 7.18 & 7.18 & 7.18 & 7.18 & 7.18 & 7.26 & 7.26 & 7.26 & 5.75 & 7.72 & 7.09 & - & & & \\
\hline $14 P . \mathrm{nr}$ minutus (Af) & 6.66 & 6.75 & 6.75 & 6.75 & 6.75 & 6.75 & 6.84 & 6.84 & 6.66 & 5.40 & 6.93 & 6.48 & 1.33 & $\cdot$ & & \\
\hline 15 P. bicolor $(\mathrm{Pa})$ & 10.72 & 10.81 & 10.81 & 10.81 & 10.81 & 10.81 & 10.90 & 10.90 & 10.72 & 9.39 & 10.74 & 10.63 & 9.84 & 9.95 & - & \\
\hline 16 P. quadrifasciatus $(\mathrm{Pa})$ & 10.72 & 10.81 & 10.81 & 10.81 & 10.81 & 10.81 & 10.90 & 10.90 & 10.72 & 10.33 & 11.27 & 10.72 & 10.63 & 10.75 & 5.93 & - \\
\hline
\end{tabular}



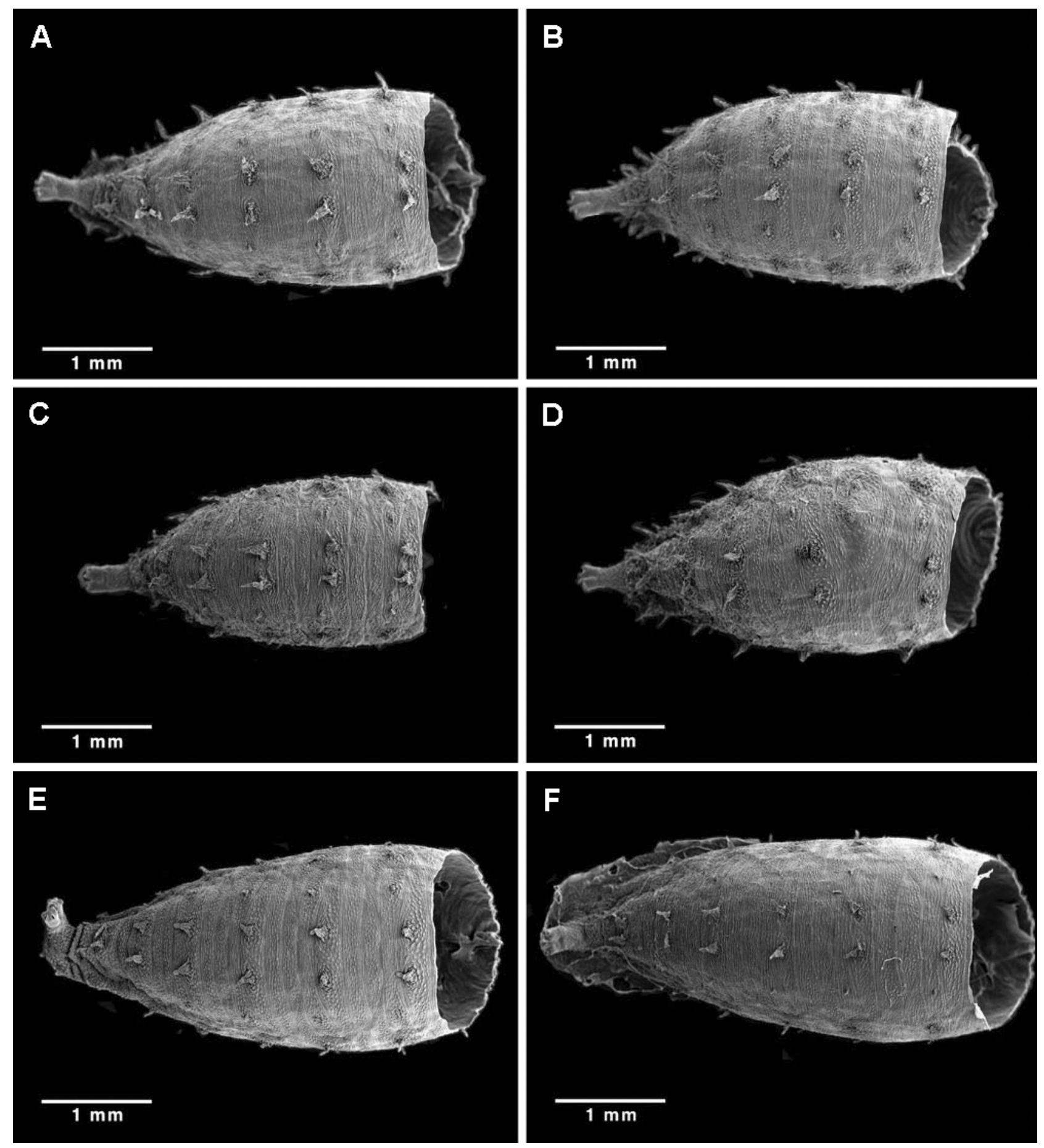

Fig. 8. Scanning electron micrographs showing the variability in the puparia of West Palaearctic P. haemorrhous (A, B), P. tibialis $(\mathrm{C}, \mathrm{D}, \mathrm{F})$ and $P$. coadunatus $(\mathrm{E})$.

longiventris Loew, 1857 (subgenus type) and indicated the more common form (pp. 108-109).

Goeldlin de Tiefenau (1976) established the main Pandasyopthalmus species of the West Palaearctic region, primarily using the shape and size of the postgonites. Later, Speight (1978) indicated that the range of variation exhibited by $P$. haemorrhous in the British Isles was greater than might have been expected. Vockeroth (1986) also found variability in the genitalia structures of Paragus haemorrhous, especially in the shape and size of the postgonites: “...the two extremes taken alone would suggest that at least two species occur in North America, but a division into two or more discrete groups appears impossible". Thompson \& Ghorpadé (1992) reported that the shape of the postgonites also varies greatly in some Oriental species of the tibialis-group.

Our hypothesis is that $P$. haemorrhous and $P$. tibialis represent the extremes of postgonite variation in the West Palaearctic region, and the intermediates could include other tibialis-group species of this region (see Fig. 1). 

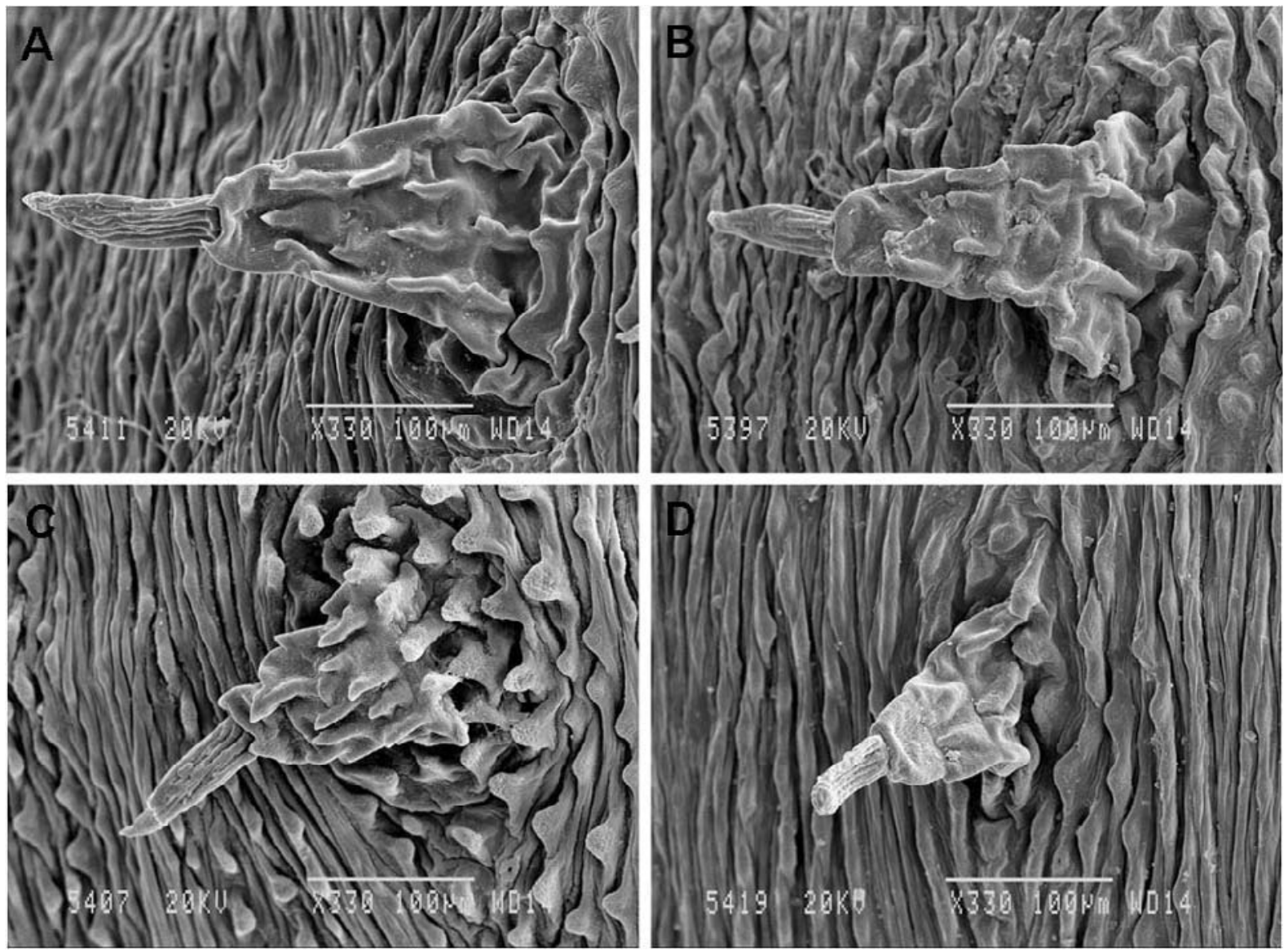

Fig. 9. Detail of sensilla from puparia of West Palaearctic P. haemorrhous (A, C) and P. tibialis (B, D).

Some European species, such as $P$. albipes and $P$. coadunatus (with small postgonites), are thus included in the variation found in $P$. haemorrhous in different parts of the world (see Speight, 1978). Similarly, larger postgonites, as in $P$. constrictus, are included in the range of variation of $P$. tibialis. In fact, Speight \& Chandler (1995), in agreement with Doczkal (1996), speculated that some of the supposed variation in P. tibialis in certain parts of Europe is due to the inclusion of $P$. constrictus.

In the subgenus Paragus s. str., the size of the postgonites is clearly smaller than that of the surstyli. In this group the postgonites together with the morphology of other parts of the hypandrium provide useful characters for species identification. As stated in Dušek \& Láska (1987), understanding the mating behaviour is important in evaluating the function of structures of the male genitalia during copulation. This information should be used to assess different taxonomic value of these structures.

In the case of females, Speight \& Chandler (1995) indicated that $P$. haemorrhous could be separated from $P$. tibialis by the former having abdominal transverse bands of black and reclined setae. Nevertheless, this character does not allow confident separation of the females of the tibialis-group. According to our results, a relation seems to exist in most of the Palaearctic species between males with small postgonites and females with these setae $(P$. haemorrhous / P. coadunatus) and males with larger postgonites and females without setae $(P$. tibialis / P. constrictus), but this character is very variable.

\section{Immature morphology}

Previously, only the chaetotaxy of the thoracic and abdominal segments of syrphid larvae has been described (Hartley, 1961; Rotheray \& Gilbert, 1999). This is the first time that larval cephalic setae are described for this family. As far as we know, the only published description of the chaetotaxy of Paragus is by Tawfik et al. (1974) for Paragus (s. str.) compeditus (Macquart, 1850). However, they apparently ignored most of the ventral setae and misinterpreted the limits of the head and thorax, and the limits of the pro-, meso- and metathorax. The result is that their reported "prothorax" is the mesothorax, and their "mesothorax" + "methatorax" [sic] are, in reality, the metathorax. Accordingly, their "cephalic setae" actually belong to the prothorax. Rotheray \& Gilbert (1989) indicated that there are no setae on the ventral surface of predacious larvae, except on the metathorax of Eupeodes Osten Sacken, 1877 and Scaeva Fabricius, 1805. This condition also exists in Paragus larvae. There is one extra pair of sensory organs near sensilla 7 on both the mesoand metathorax not recorded in the previously reported pattern of chaetotaxy. The colour and size of sensilla of the larvae are quite variable.

We are not able to define any qualitative differences between the larvae or puparia of the species of the 


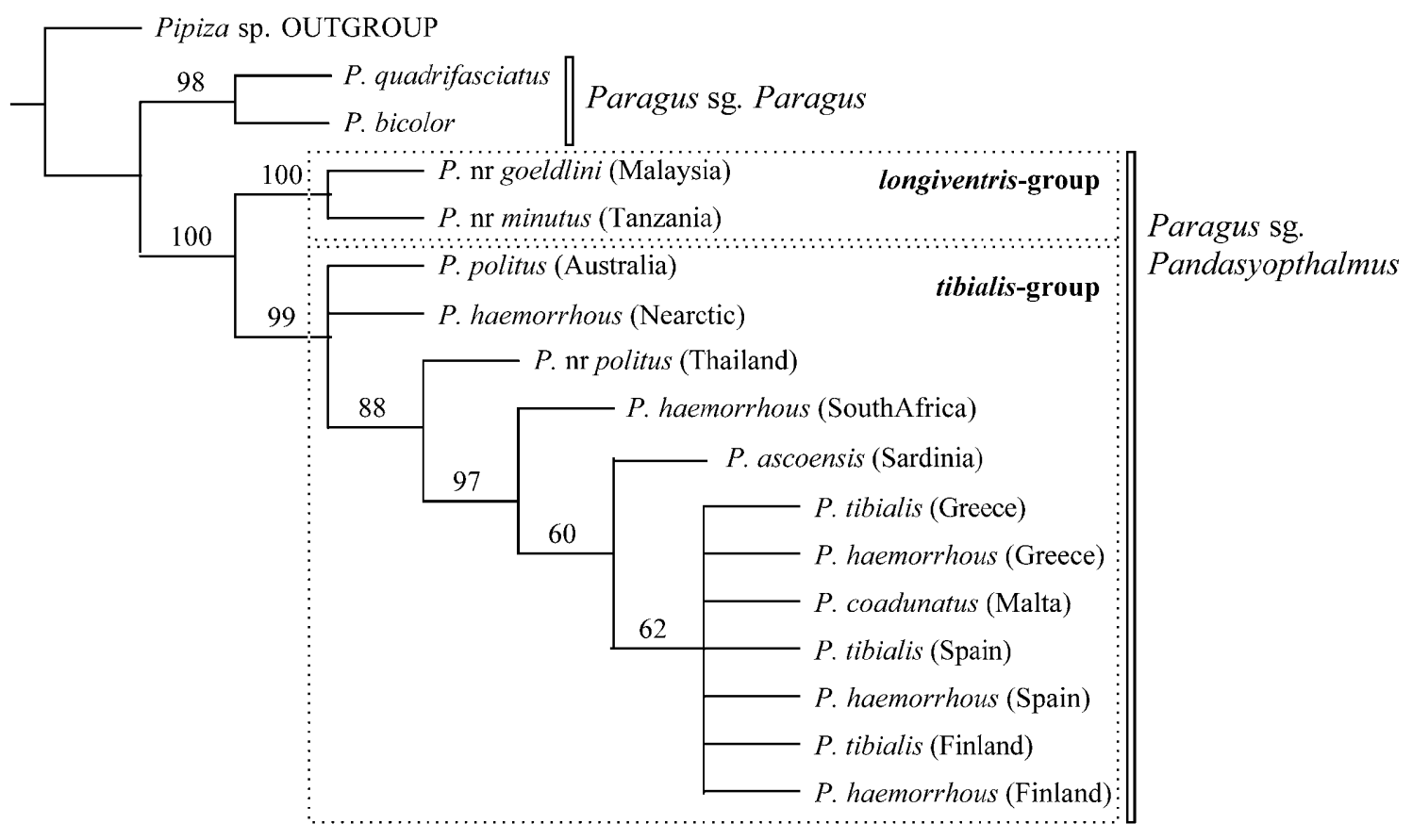

Fig. 10. Strict consensus of two equally parsimonious trees using Nona, with length $=355$ steps, $\mathrm{CI}=0.83$, and RI $=0.82$. Bootstrap support values indicated on nodes.

tibialis-group studied; only a gradient in sensilla size exists (Fig. 8). When attempting to distinguish $P$. haemorrhous from $P$. tibialis, two extremes of variability in the length of sensilla were found. Puparia with long sensilla belonged to $P$. haemorrhous (based on rearing and identifying the adult). Puparia with short sensilla were generally $P$. tibialis, however, intermediates exist that cannot be assigned to either species (see Fig. 8). The length of the pupal sensilla of $P$. coadunatus lies between these extremes.

There were no difference in the posterior spiracle, of the taxa studied; this feature, however, is useful for distinguishing species of subgenus Paragus s. str. (Goeldlin de Tiefenau, 1974; unpubl. data). Moreover, the colour of mature larvae is quite variable, with all gradations between the different patterns (see also Heiss, 1938).
Based on our studies, it is impossible to establish two or more discrete groups based on larval or puparial morphology in the species of the tibialis-group studied, whereas larval distinction between species exist in Paragus s. str. or other syrphid genera (e.g. Rotheray, 1993; Pérez-Bañón \& Marcos-García, 2000; Pérez-Bañón et al., 2003a,b).

\section{Molecular variation}

Molecular evidence in the mitochondrial COI support the monophyly of the subgenus Pandasyopthalmus, including the two groups of this lineage (Fig. 10). However, molecular analysis revealed no significant intra- or interspecific variation in the $1128 \mathrm{bp}$ fragment of the mitochondrial COI between West Palaearctic individuals of $P$. haemorrhous, $P$. tibialis, $P$. coadunatus and $P$. ascoensis from different countries, and the uncorrected

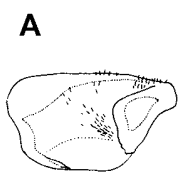

C
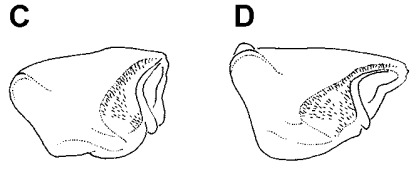

B

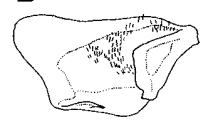

E

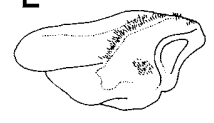

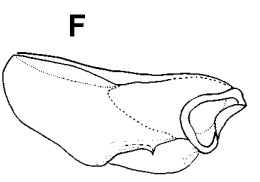

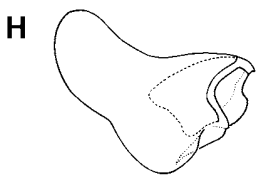

G

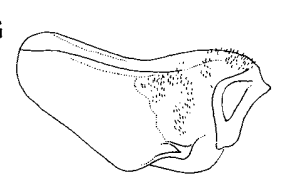

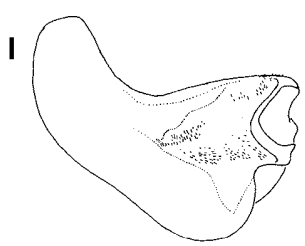

Fig. 11. Patterns of the sclerotised and membraneous areas and arrangement of microtrichia on the inner surfaces of the postgonites of some Palaearctic and Oriental tibialis-group species (lateral view). A, B - P. haemorrhous (Germany); C - P. rufocinctus (Vietnam); D - P. rufocinctus (Burna, type); E - P. abrogans (Turkey); F, G - P. constrictus (Germany); H - P. tibialis (Germany); H - P. tibialis (Turkey). Adapted from: F, H: Doczkal, 1996; A, B, C, D, E, G, I: Claussen \& Weipert, 2004. (No scale available for drawings, in the originals). 
pairwise divergences ranged from 1.1-2.7\% when comparing tibialis-group species from other biogeographical regions. However, clear differences between the species of Paragus s. str. and those of the tibialis- and longiventris-groups of the subgenus Pandasyopthalmus were found (Table 6). These levels are similar to the divergences between species found in other subgenera and genera of Syrphidae (Ståhls \& Nyblom, 2000; PérezBañón et al., 2003a; Ståhls et al., 2003) for the same gene. The divergences from the Australian-Oriental taxa could be related to differences in hypandrium morphology, e.g., P. politus lacks the dorso-lateral carina, present in the Palaearctic $P$. tibialis (see Thompson \& Ghorpadé, 1992). As the Nearctic tibialis-group specimens used for sequencing were old (1999) and not explicitly collected for DNA studies, the sequencing was difficult. Additional studies, using fresh Nearctic specimens, are necessary for a complete understanding of the existing divergences. Hebert et al. (2003b) extracted COI sequences for 1429 congeneric species pairs of Diptera from GenBank, and showed that $0.9 \%$ of these expressed sequence divergences between $0-1 \%$, indicating that these low levels reflect a short history of reproductive isolation. The mean value of sequence divergence for Diptera in the above mentioned study was $9.3 \%$ between congeneric species pairs.

The nuclear ITS2 region sequenced from twelve individuals of $P$. ascoensis, $P$. coadunatus, $P$. haemorrhous and $P$. tibialis, and from different geographic regions, revealed four different haplotypes. Dinucleotide (microsatellite) variation is generally regarded as intra-specific variation and hence exclusively used in population genetic studies. The haplotypes we found were not distributed according to geographic region or species (Table $5)$. If the distribution of haplotypes was an artefact of flawed species identifications, the expectation is a consistent pattern in conflict with species labels, but we are confident of the identification of $P$. tibialis and the variable haplotypes. Our results could represent a random sample of ITS2 haplotypes present both at intra-individual and/or the intra-species level, which do not define populations (or species). When inferring phylogenetic affiliations between populations or cryptic species that (seem to) exhibit intra-genomic variation, extensive sequencing of multiple clones / individual or multiple individuals from a large geographic range should be carried out to determine the level of variability, as intra-genomic variability could affect phylogenetic conclusions.

\section{West Palaearctic Pandasyopthalmus: One morphologically polymorphic species?}

Based on our findings, it is suggested that the male genital characters used for species recognition in the West Palaearctic tibialis-group (size and shape of postgonites) are insufficient to establish species boundaries. Moreover some species are still of uncertain status (e.g., abrogans/ albipes/constrictus complex, see Speight, 2003). Although the some authors consider that the shape of postgonites varies greatly in this group of Syrphidae (Vockeroth, 1986; Thompson \& Ghorpadé, 1992), others (e.g. Doczkal, 1996; Claussen \& Weipert, 2004) claim that Palaearctic and Oriental species of the tibialis-group, are morphologically very similar yet separable in most cases by the extent of the sclerotised and membraneous areas and arrangement of microtrichia on the inner surface of the postgonites (Fig. 11). However, the variability that we found in larval morphology overlapped when considering actual species definitions. Moreover, the molecular sequences generated indicate that the Palaearctic species studied herein represent one polymorphic taxon, as well-characterized lineages could not be obtained. Therefore, based on both morphological and molecular evidence, Paragus haemorrhous Meigen, 1822, Paragus coadunatus (Rondani, 1847) and Paragus ascoensis Goeldlin de Tiefenau \& Lucas, 1981 appear to be synonyms of Paragus tibialis (Fallén, 1817). Other Palaearctic species of the tibialis-group, for which we do not have molecular data, might also belong to this polymorphic taxon. As the type material of the tibialis-group taxa was not studied, we hesitate to make actual taxonomic changes. Molecular analysis of type material is obviously impossible or very difficult. Further study of Nearctic and Palaearctic $P$. haemorrhous material might show that they are separate species (based on molecular data).

Finding a good molecular marker can be a complicated process, especially for phylogenetic studies of closely related species. We have used markers that are presently commonly used at the taxonomic levels of species and intra-specific groupings in syrphid flies (Milankov et al., 2005; Láska et al., unpubl. data), but our results are not constrained by geographic region or species. Based on those results, the existence of a single polymorphic widespread species of the tibialis-group at least in the West Palaearctic region is proposed, as no stable morphological characters could be found for separating the taxa and the molecular characters support this hypothesis. On the other hand, if speciation in the tibialis-group was very recent, with the number of lineages exceeding the number of presently described taxa, and the levels of morphological variation still very low, even the rapidly evolving ITS2 molecular marker would not immediately reveal this variability. The levels of variation between other closely related syrphid species in ITS2 far exceed the present level (Láska et al., unpubl. data).

Presented here is the first comprehensive study of the West Palaearctic Pandasyopthalmus taxa using several character systems. The interpretation of the results is, however still preliminary. Additional data is needed for an extended study, involving extensive species and specimen sampling for sequencing of rapidly evolving intron regions as well as the ITS2, in addition to applying more traditional allozyme markers. Despite the vague conclusions, this work is a relevant addition to the recent discussions of the merits of DNA barcoding and demonstrates a case where an understanding of the taxonomy of a particular group of very closely related species is challenged using all character systems, including COI barcode sequences. 
ACKNOWLEDGEMENTS. We are greatly indebted to the following for the loan or providing the specimens used in the study: N. Laurenne (Finland), S. Marshall (Canada), D. Quicke (England), J. Skevington (Australia), M.C.D. Speight (Ireland), A. Vujic (Serbia \& Montenegro), M.J. Ebejer (Malta), M. Pita (Madeira), L. Mazánek (Czech Republic), M. Sullivan (England), M. Hauser (Germany), J. Kahanpää (Finland). We are also grateful to G. Rotheray (Scotland) for his valuable information on larval morphology. The illustrations of female terminalia were kindly produced by A. Gámez (Mexico). Financial support was provided by the Finnish Carl Cedercreutz Foundation, the Spanish Ministry of Environment (projects 040/2002) and University of Alicante (Spain) (GRE04-25). We thank J. Skevington and two anonymous reviewers for their comments, which greatly improved the manuscript.

\section{REFERENCES}

Alvarez J.A. \& Hoy M.A. 2002: Evaluation of the ribosomal ITS2 DNA sequences in separating closely related populations of the parasitoid Ageniaspis (Hymenoptera: Encyrtidae). Ann. Entomol. Soc. Am. 95: 250-256.

Beebe N.W. \& Saul A. 1995: Discrimination of all members of the Anopheles punctulatus complex by polymerase chain reaction - restriction fragment length polymorphism analysis. Am. J. Trop. Med. Hyg. 53: 478-481.

BezzI M. 1915: The Syrphidae of the Ethiopian Region Based on Material in the Collection of the British Museum (Natural History) with Descriptions of New Genera and Species. British Museum (Natural History), London, 146 pp.

Campbell R.E. \& Davidson W.M. 1924: Notes on aphidophagous Syrphidae of southern California. II. Bull. S. Calif. Acad. Sci. 23: 59-71.

Claussen C. \& Weipert J. 2004: Notes on the subgenus Paragus (Pandasyopthalmus) (Diptera, Syrphidae) from Nepal, with the description of a new species. Volucella 7: 75-88.

Clary D.O. \& Wolstenholme D.R. 1985: The mitochondrial DNA molecule of Drosophila yakuba: nucleotide sequence, gene organization, and genetic code. J. Mol. Evol. 22: 252-271.

Cheng X., Lu J., Huang C., Zhou H., Dai Z. \& Zhang G. 2000: Determination of phylogenetic position of Pipizini (Diptera: Syrphidae): based on molecular biological and morphological data. Sci. China (C, Life Sci.) 43: 146-156.

Courtney G.W., Sinclair B.J. \& Meier R. 2000: Morphology and terminology of Diptera larvae. In Papp L. \& Darvas B. (eds): Contributions to a Manual of Palaearctic Diptera (with Special Reference to Flies of Economic Importance). Vol. 1. Science Herald, Budapest, pp. 85-161.

Daminova D. 1975: On the biology of the predatory fly Paragus tibialis Flln. In: Khairutdinov Kh.Sh. \& Davletshina A.G. (eds): Ecology and Biology of the Animals of Uzbekistan. Part 1. Invertebrates. Fan, Tashkent, pp. 88-92.

Dirickx H.G. 1994: Atlas des Diptères syrphides de la région méditerranéenne. Doc. Trav. Inst. R. Sci. Nat. Belg. 75: $1-317$.

Dixon T.J. 1960: Key to and descriptions of the third instar larvae of some species of Syrphidae (Diptera) occurring in Britain. Trans. Entomol. Soc. Lond. 112: 345-379.

DoczKal D. 1996: Schwebfliegen aus Deutschland: Erstnachweise und wenig bekannte Arten (Diptera, Syrphidae). Volucella 2: 36-62.

DušEK J. \& LÁSKA P. 1987: Copulation behaviour and modification of male terminalia in the subfamily Syrphinae (Diptera). Acta Entomol. Bohemoslov. 84: 335-341.
Folmer O., Black M.B., Hoch W., Lutz R.A. \& Vrijechock R.C. 1994: DNA primers for amplification of mitochondrial cytochrome c oxidase subunit I from diverse metazoan invertebrates. Mol. Mar. Biol. Biotech. 3: 294-291.

Goeldlin de Tiefenau P. 1974: Contribution à l'étude systématique et écologique des Syrphidae (Dipt.) de la Suisse occidentale. Mitt. Schweiz. Entomol. Ges. 47: 151-251.

Goeldlin de Tiefenau P. 1976: Révision du genre Paragus (Dipt. Syrphidae) de la région paléarctique occidentale. Mitt. Schweiz. Entomol. Ges. 49: 79-108.

Goloboff P.A. 1993: NONA. Noname (a bastard son of PeeWee), version 2.0 (32 bit version). Program and documentation. Computer program distributed by J.M. Carpenter, American Museum of Natural History, New York.

HARRIS D.J. \& CRANDALL K.A. 2000: Intragenomic variation within ITS1 and ITS2 of freshwater crayfishes (Decapoda: Cambaridae): implications for phylogenetic and microsatellite studies. Mol. Biol. Evol. 17: 284-291.

Hartley J.C. 1961: A taxonomic account of the larvae of some British Syrphidae. Proc. Zool. Soc. Lond. 33: 505-573.

HARTLEY J.C. 1963: The cephalopharyngeal apparatus of syrphid larvae and its relationship to other Diptera. Proc. Zool. Soc. Lond. 141: 261-280.

Hebert P.D.N., Cywinska A., Ball S.L. \& Dewaard J.R. 2003a: Biological identifications through DNA barcodes. Proc. $R$. Soc. Lond. (B, Biol.) 270: 313-322 (DOI 10.1098/rspb.2002. 2218).

Hebert P.D.N., Ratnasingham S. \& Dewaard J.R. 2003b: Barcoding animal life: cytochrome c oxidase subunit 1 divergences among closely related species. Proc. R. Soc. Lond. (B, Biol.) 270: S96-S99 (DOI 10.1098/rsbl.2003.0025).

HeIss E.M. 1938: A classification of the larvae and puparia of the Syrphidae of Illinois, exclusive of the aquatic forms. Univ. Illinois Bull. 36: 1-142.

Kassebeer C.F. 1999: Die Gattung Paragus Latreille, 1804 (Diptera, Syrphidae) in der Elfenbeinküste. Dipteron 2: 31-44.

Kertész K. 1910: Catalogus Dipterorum hucusque descriptorum. Vol. 7. Syrphidae, Dorylaidae, Phoridae, Clythiidae. Wilhelm Engelman, Budapest, $470 \mathrm{pp}$.

Láska P., Pérez-Bañón C., Mazánek L., Rojo S., StÅhls G., Marcos-García M.A., Bičík V. \& DušEK J. 2006: Taxonomy of Palaearctic species of genus Scaeva, and genera Ischiodon and Simosyrphus (Diptera, Syrphidae): descriptions of immature stages and status of taxa. Eur. J. Entomol. 103 (in press).

Leo N.P. \& BARKER S.C. 2002: Intragenomic variation in ITS2 rDNA in the louse of humans, Pediculus humanus: ITS2 is not a suitable marker for population studies in this species. Insect Mol. Biol. 11: 651-657.

Metcalf C.L. 1911: Life histories of Syrphidae. II. Ohio Nat. 12: $397-404$.

Metcalf C.L. 1913: Life histories of Syrphidae. V. Ohio Nat. 13: 81-93.

Milankov V., Stamenković J., Ludoški J., StÅhls G. \& Vujić A. 2005: Diagnostic molecular markers and genetic relationships among three species from the Cheilosia canicularis group (Diptera: Syrphidae). Eur. J. Entomol. 102: 125-131.

Ngamo Tinkeu L.S. \& Hance T. 2002: Les sensilles du premier somite des larves de Episyrphus balteatus (Diptera Syrphidae). Belg. J. Entomol. 4: 33-40.

Nixon K.C. 2002: WinClada ver. 1.00.08. Published by the author, Ithaca, New York.

Paskewitz S.M., Wesson D.M. \& Collins F.H. 1993: The internal transcribed spacers of ribosomal DNA in five members of the Anopheles gambiae species complex. Insect Mol. Biol. 2: 247-257. 
Peck L.V. 1988: Family Syrphidae. In Soós Á. (ed.): Catalogue of Palaearctic Diptera. Syrphidae-Conopidae. Vol. 8. Akad. Kiado, Budapest, pp. 11-230.

Pérez-Bañón C. \& Marcos-García M.A. 2000: Description of immature stages of Syritta flaviventris (Diptera: Syrphidae) and new data about the life history of European species of Syritta on Opuntia maxima. Eur. J. Entomol. 97: 131-136.

Pérez-Bañón C., Rojo S., Ståhls G. \& Marcos-García M.A 2003a: Taxonomy of European Eristalinus Fabricius, 1805 (Diptera: Syrphidae) using larval morphology and molecular data. Eur. J. Entomol. 100: 417-428.

Pérez-Bañón C., Rotheray G., Hancock G., Marcos-García M.A. \& ZumBaDo M.A. 2003b: Immature stages and breeding sites of some Neotropical saprophagous syrphids (Diptera, Syrphidae). Ann. Entomol. Soc. Am. 96: 458-471.

RotherAy G.E. 1991: Larval stages of 17 rare poorly known British hoverflies (Diptera: Syrphidae). J. Nat. Hist. 25: 945-969.

Rotheray G.E. 1993: Colour Guide to Hoverfly Larvae (Diptera, Syrphidae) in Britain and Europe. Dipterist Digest No. 9, Sheffield, $156 \mathrm{pp}$.

Rotheray G.E. \& Gilbert F. 1989: The phylogeny and systematics of European predacious Syrphidae (Diptera) based on larval and puparial stages. Zool. J. Linn. Soc. 95: 29-70.

Rotheray G.E. \& Gilbert F. 1999: Phylogeny of Palaearctic Syrphidae (Diptera): evidence from larval stages. Zool. J. Linn. Soc. 127: 1-112.

SACK P. 1929: Die Fliegen der paläarktischen Region. Bd. 4. Stuttgart, $451 \mathrm{pp}$.

Sharpe R.G., Harbach R.E. \& Butlin R.K. 2000: Molecular variation and phylogeny of members of the Minimus group of Anopheles subgenus Cellia (Diptera, Culicidae). Syst. Entomol. 25: 263-272.

Simon C., Frati F., Beckenbach A., Crespi B., Liu H. \& Flook P. 1994: Evolution, weighting and phylogenetic utility of mitochondrial gene-sequences and a compilation of conserved polymerase chain-reaction primers. Ann. Entomol. Soc. Am. 87: 651-701.

SINCLAIR B.J. 2000: Morphology and terminology of Diptera male terminalia. In Papp L. \& Darvas B. (eds): Contributions to a Manual of Palaearctic Diptera (with Special Reference to Flies of Economic Importance). Vol. 1. Science Herald, Budapest, pp. 53-74.
Skevington J.H. \& Yeates D.K. 2000: Phylogeny of the Syrphoidea (Diptera) inferred from mtDNA sequences and morphology with particular reference to classification of the Pipunculidae (Diptera). Mol. Phylogenet. Evol. 16: 212-224.

Speight M.C.D. 1978: The genus Paragus (Dipt.: Syrphidae) in the British isles, including a key to known and possible British isles species. Entomol. Rec. 90: 100-107.

SpeIGHT M.C.D. 2003: Species accounts of European Syrphidae (Diptera) 2003. In Speight M.C.D., Castella E., Obrdlik P. \& Ball S. (eds): Syrph the Net, the Database of European Syrphidae. Vol. 39. Syrph the Net publications, Dublin, 209 pp.

Speight M.C.D. \& Chandler P.J. 1995: Paragus constrictus, Pteromicra pectorosa and Stegana similis: insects new to Ireland and Stegana coleoptrata, presence in Ireland confirmed (Diptera). Irish Nat. J. 25: 28-32.

StÅnls G. \& Nyblom K. 2000: Phylogenetic analysis of the genus Cheilosia (Diptera, Syrphidae) using mitochondrial COI sequence data. Mol. Phylogenet. Evol. 15: 235-241.

Stånls G., Hippa H., Rotheray G., Muona J. \& Gilbert F. 2003: Phylogeny of Syrphidae (Diptera) inferred from combined analysis of molecular and morphological characters. Syst. Entomol. 28: 433-450.

StUCKenBerg B.R. 1954: Studies on Paragus, with description of new species (Diptera, Syrphidae). Rev. Zool. Bot. Afr. 49: 97-139.

Tawfik M.F.S., Azab A.K. \& Awadallah K.T. 1974: Studies on the life-history and description of the immature forms of the Egyptian aphidophagous syrphids. II - Paragus aegyptius Macq. Bull. Soc. Entomol. Egypte 58: 35-54.

THOMPSON F.C. \& GHORPADÉ K. 1992: A new coffee aphid predator, with notes on other Oriental species of Paragus (Diptera: Syrphidae). Colemania 5: 1-24.

THOMPson F.C. \& Rotheray G.E. 1998: Family Syrphidae. In Papp L. \& Darvas B. (eds): Contributions to a Manual of Palaearctic Diptera (with Special Reference to Flies of Economic Importance). Vol. 3. Science Herald, Budapest, pp. 81-139.

VoCKEROTH J.R. 1986: Revision of the new world species of Paragus Latreille (Diptera: Syrphidae). Can. Entomol. 118: 183-198.

Vujic A., Radenkovic S. \& Stanescu C. 1998: New data on hoverflies (Diptera, Syrphidae) in Romania. Volucella 3: 63-74.

Received May 6, 2005; revised and accepted September 9, 2005 